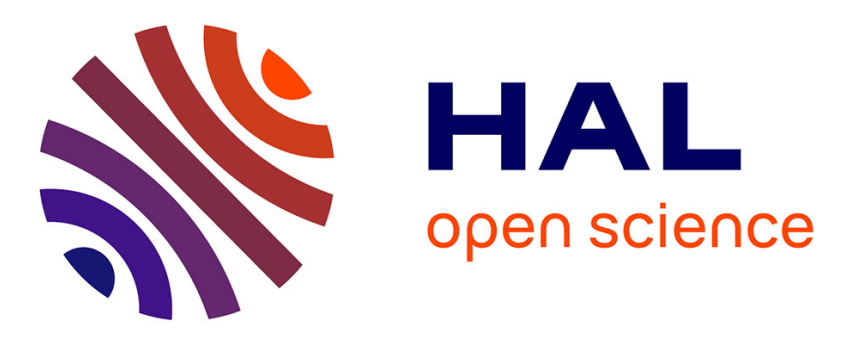

\title{
Ocean acidification and temperature rise: effects on calcification during early development of the cuttlefish Sepia officinalis
}

\author{
Narimane Dorey, Frank Melzner, Sophie Martin, François Oberhänsli, \\ Jean-Louis Teyssié, Paco Bustamante, Jean-Pierre Gattuso, Thomas \\ Lacoue-Labarthe
}

\section{To cite this version:}

Narimane Dorey, Frank Melzner, Sophie Martin, François Oberhänsli, Jean-Louis Teyssié, et al.. Ocean acidification and temperature rise: effects on calcification during early development of the cuttlefish Sepia officinalis. Marine Biology, 2013, 160 (8), pp.2007-2022. 10.1007/s00227-012-2059-6 . hal-00855750

\author{
HAL Id: hal-00855750 \\ https://hal.science/hal-00855750
}

Submitted on 30 Aug 2013

HAL is a multi-disciplinary open access archive for the deposit and dissemination of scientific research documents, whether they are published or not. The documents may come from teaching and research institutions in France or abroad, or from public or private research centers.
L'archive ouverte pluridisciplinaire HAL, est destinée au dépôt et à la diffusion de documents scientifiques de niveau recherche, publiés ou non, émanant des établissements d'enseignement et de recherche français ou étrangers, des laboratoires publics ou privés. 


\title{
Ocean acidification and temperature rise: effects on calcification during early development of the cuttlefish Sepia officinalis
}

\author{
Narimane Dorey ${ }^{\mathrm{a}, \mathrm{h}}$, Frank Melzner ${ }^{\mathrm{b}}$, Sophie Martin ${ }^{\mathrm{a}, \mathrm{e}, \mathrm{f}}$, François Oberhänsli ${ }^{\mathrm{a}}$, Jean-Louis Teyssié , $^{\mathrm{a}}$ \\ Paco Bustamante $^{\mathrm{c}}$, Jean-Pierre Gattuso ${ }^{\mathrm{d}, \mathrm{g}}$, Thomas Lacoue-Labarthe $\mathrm{e}^{\mathrm{a}, \mathrm{c}, \mathrm{d}}$ *
}

a. International Atomic Energy Agency - Environment Laboratories (IAEA-EL), 4 Quai Antoine $\mathrm{I}^{\mathrm{er}}, \mathrm{MC}-98000$ Principality of Monaco

b. Biological Oceanography, Helmholtz Centre for Ocean Research (GEOMAR), 24105 Kiel, Germany

c. Littoral, Environnement et Sociétés (LIENSs), UMR 7266, CNRS-Université de La Rochelle, 2 rue Olympe de Gouges, F-17042 La Rochelle Cedex 01, France

d. Université Pierre et Marie Curie-Paris 6, Observatoire Océanologique de Villefranche, 06230 Villefranche-sur-Mer, France

e. CNRS, Laboratoire Adaptation et Diversité en Milieu Marin, Station Biologique de Roscoff, Place Georges Teissier, 29682 Roscoff Cedex, France

f. Université Pierre et Marie Curie, Paris 06, Laboratoire Adaptation et Diversité en Milieu Marin, Station Biologique de Roscoff, Place Georges Teissier, 29682 Roscoff Cedex, France

g. CNRS-INSU, Laboratoire d'Océanographie de Villefranche, BP 28, 06234 Villefranche-sur-Mer Cedex, France.

h. Department of Biological and Environmental Sciences, The Sven Lovén Center for Marine Science, University of Gothenburg, Kristineberg, 45034 Fiskebäckskil, Sweden

Correspondence to: Ms Narimane Dorey

Address: Department of Biological and Environmental Sciences,

The Sven Lovén centre for Marine Sciences - Kristineberg,

University of Gothenburg,

45034 Fiskebäckskil, Sweden

Phone: $\quad+46(0)$ 766-22 9529

Fax: $\quad$ +46 (0) 523-18502

E-mail: narimane.dorey@gu.se

*present address: tlacouel@gmail.com 


\section{$\underline{\text { Abstract: }}$}

This study investigated the effects of seawater $\mathrm{pH}$ (i.e. 8.10, 7.85 and 7.60) and temperature (16 and $19^{\circ} \mathrm{C}$ ) on (i) the abiotic conditions in the fluid surrounding the embryo (viz. the perivitelline fluid), (ii) growth, development and (iii) cuttlebone calcification of embryonic and juvenile stages of the cephalopod Sepia officinalis. Egg swelling increased in response to acidification or warming, leading to an increase in egg surface while the interactive effects suggested a limited plasticity of the swelling modulation. Embryos experienced elevated $p \mathrm{CO}_{2}$ conditions in the perivitelline fluid (> 3-fold higher $p \mathrm{CO}_{2}$ than that of ambient seawater), rendering the medium under-saturated even under ambient conditions. The growth of both embryos and juveniles was unaffected by $\mathrm{pH}$, whereas ${ }^{45} \mathrm{Ca}$ incorporation in cuttlebone increased significantly with decreasing $\mathrm{pH}$ at both temperatures. This phenomenon of hypercalcification is limited to only a number of animals but does not guarantee functional performance and calls for better mechanistic understanding of calcification processes.

Keywords: early-life stages; calcification; cephalopod; Sepia officinalis; ocean acidification; global warming; Ca-45 


\section{INTRODUCTION}

Marine calcifying organisms were expected to be particularly impacted by ocean acidificationdriven changes in marine carbonate chemistry (Seibel and Fabry 2003; Orr et al. 2005; Langdon and Atkinson 2005; Kleypas et al. 2006). Our current knowledge supports the hypothesis that a broad range of them indeed undergo reduced calcification or increased dissolution rates in response to predicted atmospheric $p \mathrm{CO}_{2}$ increases (see review by Kroeker et al. 2010): corals (see review by Hoegh-Guldberg et al. 2007), planktonic foraminifera (e.g. Spero et al. 1997; Bijma et al. 2002), coccolithophores (e.g. Riebesell et al. 2000; Zondervan et al. 2001), bivalves (e.g. Gazeau et al. 2010, 2011; Waldbusser et al. 2010; Thomsen et al. 2010), pteropods (e.g. Comeau et al. 2011) or echinoderms (reviewed by Dupont et al. 2010). Some studies however reported unchanged or increased calcification rates under high seawater $\mathrm{CCO}_{2}$ in echinoderms (Wood et al. 2008; Gooding et al. 2009; Ries et al. 2009), decapod crustaceans (Ries et al. 2009), juvenile cephalopods (Gutowska et al. 2010a,b), and teleost fish (otholiths: Checkley et al. 2009; Munday et al. 2011). Seibel and Walsh (2001, 2003) and Seibel and Fabry (2003) hypothesized that adults or juveniles of active species with high metabolic rates are not impaired as negatively by ocean acidification as species with lower metabolic rates. Highly mobile and active marine organisms (teleost fish, cephalopods and many brachyuran crustaceans) need a powerful ion regulatory apparatus to maintain constant blood $\mathrm{pH}$ despite fluctuations in blood / haemolymph and seawater $p \mathrm{CO}_{2}$. This ability to efficiently regulate extracellular $\mathrm{pH}$ could be one explanation for the increased tolerance of some organisms to projected increases in future $p \mathrm{CO}_{2}$ (Melzner et al. 2009). These processes, controlled by ion-transporter fueled by ATP-dependent pumps, may be energetically costly to maintain in acidified conditions ( $\mathrm{Hu}$ et al. 2011a). Yet, ocean acidification will act simultaneous with other climate-related variables, including a global temperature rise. The interaction between these two co-occurring stressors could have a larger effect on animals by accumulating metabolic additional requirements (Pörtner 2008; Blackford 2010). As an example, regarding cephalopods, Rosa and Seibel (2008) showed that the effects of hypercapnia ( 1000 $\mu$ atm, $\left.\mathrm{pH}_{\mathrm{NBS}} \sim 7.62\right)$ on the jumbo squid metabolism were more pronounced at elevated temperatures ( -15 to $-20 \%$ of oxygen consumption during resting periods at $20-25^{\circ} \mathrm{C}$ respectively vs. no effect of hypercapnia at $10^{\circ} \mathrm{C}$ ).

In organisms possessing complex life-cycles, it is often assumed that early-life stages may be the most vulnerable to environmental perturbations, including high $p \mathrm{CO}_{2}$ (Pörtner and Farell 2004; Pörtner 2008; Kurihara 2008), especially in invertebrates (e.g. Kurihara 2008; Dupont and Thorndyke 2009). Even though this view is discussed controversly (Dupont and Thorndyke 2009; Byrne 2011), projected changes in seawater abiotic conditions could have strong effects on the development of embryos, larvae and juveniles and their calcification capacities. Until now however, 
studies on the effects of high $\mathrm{pCO}_{2}$ on the calcification capacities of water-breathing marine organisms' early life stages are still scarce. On the common cuttlefish Sepia officinalis for instance, Gutowska et al. (2008) showed maintained calcification and growth in juveniles after 40 days of exposure to high $p \mathrm{CO}_{2}$. In a second study, Gutowska et al. (2010b) showed a 20-50\% increase of the $\mathrm{CaCO}_{3}$ fraction in juvenile's cuttlebones along with a structural change of the calcified matrix. It should be noted that both studies were done at much higher $p \mathrm{CO}_{2}$ than the IPCC predictions for 2100 (i.e. $~ 4000 \mu \mathrm{atm}, \mathrm{pH}_{\mathrm{NBS}} \sim 7.23$ and $\sim 6000 \mu \mathrm{atm}, \mathrm{pH}_{\mathrm{NBS}} \sim 7.10$; compared to $900 \mu \mathrm{atm}, 7.70 \mathrm{pH}$ units predicted for 2100; IPCC 2007). Additionally, very few studies have considered the impacts of global change on several successive life-stages (e.g. Parker et al. 2012, Dupont et al. 2012), while the transition from one stage to another (e.g. metamorphosis, hatching) can be radical. It has been demonstrated that, for example, juvenile performances can be impaired by stressful experiences during larval or embryonic life (Pechenik 2006).

Among the class Cephalopoda, the Sepiida (or cuttlefish) are characterized by an internal cuttlebone (Rodhouse 1998), i.e. an aragonitic-organic composite structure used as a structural skeleton that also serves as a buoyancy control device (Denton and Gilpin-Brown 1959). It is composed of a calcareous phragmocone containing several septae (i.e. delimiting lamellae), separated by small vertical pillars and walls forming chambers (Birchall and Thomas 1983). These chambers contain gas (Denton and Taylor, 1964) and are used to regulate the animal's vertical position in the water column. Cuttlefish buoyancy is adjusted by moving liquid in or out of the shell chambers via an osmotic pump (Denton and Gilpin-Brown 1961, Denton et al. 1961). The first chambers of the cuttlebone are synthesized during the embryonic phase within the egg case. Cuttlebone and associated buoyancy mechanism have to be functional upon hatching, as these necto-benthic predators immediately start to move and feed in complex three-dimensional environments (Boletzky 2003). The cuttlebone is produced rapidly, in accordance with the high, exponential growth rates observed in embryonic and juvenile cephalopods ( $c a .3 .5 \%$ of the bodyweight per day in $1.5 \mathrm{~g}$ cuttlefish at $17^{\circ} \mathrm{C}$, Forsythe et al. 2002, Melzner et al. 2005).

Among Sepiida, S. officinalis is one of the most abundant cephalopods along the European coasts, including the Mediterranean sea (Boletzky 1983). This species is commercially important in this area with landings 50,000 tons per year in Europe (Pierce et al. 2010). After a relative short life (one to two years), adults spawn and lay their eggs in shallow waters ( $<30-40 \mathrm{~m}$, Guerra, 2006) from late winter to early summer (Rodhouse 1998). In the Ligurian Sea (NW Mediterranean), water temperatures fluctuate around $15-17^{\circ} \mathrm{C}$ when cuttlefish spawning reaches its peak (March-May, 050 m, DYFAMED: http://www.obs-vlfr.fr/sodyf/). The lecithotrophic embryos then develop for a relatively long time inside the eggs (two months at $16^{\circ} \mathrm{C}$ ). Development ends with hatchlings that 
resume a necto-benthic life-style and are essentially isometric copies of adults (Melzner et al. 2007). These juveniles experience warmer waters from May to July although temperature does not yet exceed $20^{\circ} \mathrm{C}$. Regarding carbonate chemistry conditions, recent data in Ligurian Sea estimated a monthly average of surface seawater $p \mathrm{CO}_{2}$ varying throughout the year in a limited range from 300 $\mu$ atm (January-May) to $420 \mu \mathrm{atm}$ (July-September; Bégovic and Copin-Montégut 2002; Touratier and Goyet 2011).

In the egg, the embryo bathes in the perivitelline fluid (PVF) and is protected by a flexible eggshell, which serves as a protective layer against the surrounding environment (Boletzky 1986). Exchange between seawater and PVF is limited and selective in terms of water and molecules (Gomi et al. 1986; de Leersnyder and Lemaire 1972), including pollutants (Bustamante et al. 2002, 2004, 2006, Lacoue-Labarthe et al. 2009, 2010a, 2010b, 2011a, 2011b). Due to the egg case serving as a diffusion barrier for respiratory gases $\left(\mathrm{CO}_{2}, \mathrm{O}_{2}\right)$, embryos are exposed to low PVF $p \mathrm{O}_{2}\left(p \mathrm{O}_{2}<6\right.$ $\mathrm{kPa}$, Cronin and Seymour 2000, Gutowska and Melzner 2009) and to high $p \mathrm{CO}_{2}$ in turn $\left(p \mathrm{CO}_{2}>\right.$ $0.4 \mathrm{kPa}$ i.e. > 2000-4000 $\mu \mathrm{atm}$, Gutowska and Melzner 2009). PVF is also slightly hypertonic when compared to seawater (de Leersnyder and Lemaire 1972), which enables the characteristic egg swelling process (Cronin and Seymour 2000). In addition, the eggshell was shown to display a trace element selective permeability (Bustamante et al. 2002, 2004, 2006; Lacoue-Labarthe et al. 2008, 2009, 2010a, 2011a). Consequently, the embryo grows under abiotic conditions in the PVF that are very different from those that hatchlings and juveniles encounter in the seawater.

$p \mathrm{CO}_{2}$-driven ocean warming and seawater carbonate chemistry change are likely to differently affect embryonic cuttlebone formation inside the PVF and juveniles living in seawater. To examine the effects of $\mathrm{pH}$ and temperature on the calcification capacity of S. officinalis successive early life stages (embryo and juveniles), this study investigated (1) the incorporation of the radiotracer ${ }^{45} \mathrm{Ca}$ into the cuttlebone in relation to (2) the abiotic conditions surrounding embryo and juveniles. Cuttlefish were reared during embryonic development and a significant part of early juvenile life (19 days) both at current $\mathrm{pH}(8.10)$ and at two lower $\mathrm{pH}$ treatment levels (7.85 and 7.60, as predicted for 2100); all three $\mathrm{pH}$ conditions were studied at two temperatures $\left(16\right.$ and $\left.19^{\circ} \mathrm{C}\right)$.

\section{MATERIALS AND METHODS}

\section{Animals:}

Eight S. officinalis adults were obtained from a fisherman in the Principality of Monaco in both April 2008 (“Experiment 1") and February 2009 (“Experiment 2"). Male and female cuttlefish were 
acclimated by pairs and kept in flow-through seawater aquarium systems $600 \mathrm{~L}$; temperature from 16 to $18^{\circ} \mathrm{C}$ ) in the IAEA-EL premises. They were daily fed on living shore crabs Carcinus maenas or frozen fish. After mating, fertilized eggs laid by one single female were immediately separated to optimize oxygenation and randomly distributed to the appropriate experimental treatments (2 temperature x 3 pH treatments). All animals - adults, eggs and juveniles - were reared in $0.45 \mu \mathrm{m}$ filtrated, UV sterilized and continuously aerated Mediterranean seawater (salinity: 38; light/dark cycle: $12 \mathrm{~h} / 12 \mathrm{~h})$.

\section{Experimental design:}

Experiment 1: approximately 300 newly laid eggs were randomly assigned in 6 plastic containers (one bottle per treatment) containing 5L of seawater being maintained under controlled conditions of temperature and $\mathrm{pH}$ through a crossed $(2 \times 3)$ experiment. Three incubation containers were kept in a bath maintained at $16^{\circ} \mathrm{C}$ and three in a bath at $19^{\circ} \mathrm{C}$, based on the average warming of $3^{\circ} \mathrm{C}$ of the ocean surface waters expected for the end of the century (Levitus et al. 2005). Within each temperature treatment, one container was maintained at ambient $\mathrm{pH}\left(8.10 ; p \mathrm{CO}_{2} \sim 390 \mu \mathrm{atm}\right)$ while the two others were maintained at $\mathrm{pH}$ values predicted to occur following optimistic and pessimistic future scenarios (IPCC, 2007): 7.85 ( $\left.p \mathrm{CO}_{2} \sim 800 \mu \mathrm{atm}\right)$ and 7.60 ( $\left.p \mathrm{CO}_{2} \sim 1400 \mu \mathrm{atm}\right)$. Water was renewed weekly during the first week and then every second day to maintain water quality constant $\left(\left[\mathrm{NH}_{4}^{+}\right]<0.1 \mathrm{mg} \mathrm{L}^{-1},\left[\mathrm{NO}_{2}^{-}\right]<0.1 \mathrm{mg} \mathrm{L}^{-1},\left[\mathrm{NO}_{3}{ }^{-}\right]<5 \mathrm{mg} \mathrm{L}^{-1}\right)$. Eggs from this incubation were used to follow egg mass accretion and embryonic growth (see below Embryonic and juvenile development), cuttlebone weight and ${ }^{45} \mathrm{Ca}$ accumulation (see below ${ }^{45} \mathrm{Ca}$ radiolabelling and sample treatment).

Experiment 2: egg batches were maintained during the whole embryonic development under similar conditions as described above (2 temperature x $3 \mathrm{pH}$ treatments). A sub-sample was used for abiotic conditions measurements in the PVF (see below Egg perivitelline fluid (PVF) abiotic conditions) while the remaining eggs were left to hatch. Ten days after hatching, juveniles were transferred and reared in plastic 4-L flat-bottom tanks in the same treatments as the eggs. Seawater was changed every day in all containers to maintain constant water quality and animals were fed ad libitum twice per day with live brine shrimp (Artemia salina), and juvenile shore crabs (C. maenas).

\section{Culture maintenance and seawater carbonate chemistry assessment:}

Temperatures were controlled in each bath to within $\pm 0.5^{\circ} \mathrm{C}$ (Table 1) using temperature controllers connected to $300 \mathrm{~W}$ submersible heaters. In each container, $\mathrm{pH}$ was controlled within \pm $0.05 \mathrm{pH}$ units (Table 1) by bubbling pure $\mathrm{CO}_{2}$, using a continuous $\mathrm{pH}$-stat system (IKS, Karlsbad). The $\mathrm{pH}$ values of the $\mathrm{pH}$-stat system were adjusted every two days from measurements of $\mathrm{pH}$ on the 
total scale $\left(\mathrm{pH}_{\mathrm{T}}\right)$. $\mathrm{pH}$ was measured in each bottle using a pH meter (Metrohm, $826 \mathrm{pH}$ mobile) with a glass electrode (Metrohm, electrode plus) calibrated on the total scale using Tris/HCl (TRIS) and 2-aminopyridine/HCl (AMP) buffer solutions with a salinity of 38 and prepared according to Dickson et al. (2007). Total alkalinity $\left(\mathrm{A}_{\mathrm{T}}\right)$ shifts between two seawater renewals were assessed in non-radiolabelled seawater of similar conditions ( $\mathrm{pH}$, temperature, number of living individuals). $\mathrm{A}_{\mathrm{T}}$ was measured on seawater samples filtered through $0.7 \mu \mathrm{m}$ membranes, immediately poisoned with mercuric chloride and stored in a cool dark place pending analyses. $\mathrm{A}_{\mathrm{T}}$ was determined potentiometrically using a home-made titration system, an Orion $8103 \mathrm{SC} \mathrm{pH}$ electrode calibrated on the National Bureau of Standards scale and a computer-driven Metrohm 665 Dosimat titrator. $A_{T}$ was calculated using a Gran function applied to $\mathrm{pH}$ values ranging from 3.5 to 3.0 as described by Dickson et al. (2007). The $p \mathrm{CO}_{2}$ and the aragonite saturation state $\left(\Omega_{\mathrm{ar}}\right)$ were determined from $\mathrm{pH}_{\mathrm{T}}$ and $\mathrm{A}_{\mathrm{T}}$ using the $\mathrm{R}$ package Seacarb (Lavigne and Gattuso 2009), with dissociation constants from Mehrbach et al. (1973) as refitted by Dickson and Millero (1987).

\section{Egg perivitelline fluid (PVF) abiotic conditions:}

Eggs used for $p \mathrm{O}_{2}, \mathrm{pH}_{\mathrm{SWS}}$ (SWS scale) and total dissolved inorganic carbon (CT) measurements inside the egg fluid were reared in the same temperature and $\mathrm{pH}$ cross treatments as previously described. During Experiment 2, at the end of development (stage 30 according to Lemaire 1970; i.e. days after spawning $=65$ at $16^{\circ} \mathrm{C}$ and 47 for $19^{\circ} \mathrm{C}$, Fig. 1 ), eggs ( $\mathrm{n}=8$ to 12 per conditions) were gently lifted out of the tank, weighted and measurements started immediately afterwards. PVF sampling was realized within $15 \mathrm{~s}$, thus minimizing the artificial increase of the $p \mathrm{CO}_{2}$ values caused by stressed embryos. Measurements were obtained using a $1 \mathrm{~mL}$ plastic syringe equipped with fiber optic micro-sensors (optodes, tip diameter $140 \mu \mathrm{m}$, Presens GmbH, Regensburg, Germany). Stable PVF $p \mathrm{O}_{2}$ values were obtained within $10 \mathrm{~s}$ in the syringe filled with 200-300 $\mu \mathrm{L}$ of PVF (as previously described in Gutowska and Melzner 2009). PVF pH (SWS scale) values were measured in $0.5 \mathrm{~mL}$ plastic tubes using a pH electrode (WTW Mic and WTW pH340i pH meter), with stable values reached within $1 \mathrm{~min}$. During the measurement period, the syringe and sensors were placed in a thermostatted water bath at the appropriate temperature (i.e. 16 or $19^{\circ} \mathrm{C}$ ). The oxygen optode was calibrated according to the manufacturer's instructions with water vapor saturated air and a $\mathrm{Na}_{2} \mathrm{SO}_{3}$ solution. The $\mathrm{pH}$ optode was calibrated using TRIS and AMP as described above. CT was measured in $100 \mu \mathrm{L}$ of PVF with a Corning $965 \mathrm{CO}_{2}$ analyzer in triplicates. Carbonate system parameters, i.e. $p \mathrm{CO}_{2}, \Omega_{\mathrm{ar}}$, were calculated from CT and $\mathrm{pH}_{\mathrm{Sws}}$ using CO2SYS software (Lewis and Wallace 1998), with dissociation constants from Mehrbach et al. (1973) as refitted by Dickson and Millero (1987). 


\section{Embryonic and juvenile development:}

During embryonic development, egg growth due to egg swelling was determined measuring the whole egg fresh weight, in both Experiment 1 and 2. The development course was followed by determination of the embryonic stages according to Lemaire (1970). At stage 30 during Experiment 1, embryos $(\mathrm{n}=10)$ body dry weights $\left(65^{\circ} \mathrm{C}\right.$ overnight $)$ were measured on a fine-scale balance (i.e. days after spawning $=61$ and 42 , at respectively $16^{\circ} \mathrm{C}$ and $19^{\circ} \mathrm{C}$, Fig. 1). Similarly, during Experiment 2, 19-days old juveniles ( $\mathrm{n}=5$ to 12 ; see Fig. 1 ) were immediately frozen at $-20^{\circ} \mathrm{C}$ after sampling and dry body masses were measured after $12 \mathrm{~h}$ at $65^{\circ} \mathrm{C}$.

\section{${ }^{45}$ Ca radiolabelling and samples treatment:}

Experiment 1: Seawater in each bottle was spiked with ${ }^{45} \mathrm{Ca}\left(10 \mathrm{kBq} \mathrm{L}{ }^{-1}\right)$. Radiotracers were purchased from Radioisotope Centre Polatum, Poland, ${ }^{45} \mathrm{Ca}$ [as ${ }^{45} \mathrm{CaCl}_{2} ; \mathrm{T}_{1 / 2}=163 \mathrm{~d}$ ]. Stock solutions were prepared in $\mathrm{H}_{2} \mathrm{O}$ to obtain radioactivities that allowed the use of spikes of only a few microliters (typically 5-10 $\mu \mathrm{L}$ ). The radiotracer spikes were renewed at each water change, in order to maintain radiotracer concentrations. Radiotracer activities in seawater were checked before and after each water renewal in 5-mL samples, in order to determine the time-integrated radiotracer activities (Rodriguez y Baena et al. 2006). When stage 30 was reached, 5 eggs were weighted and sampled to determine the radiotracer incorporation in the embryo. Eggs exposed to dissolved ${ }^{45} \mathrm{Ca}$ were dissected and the different egg compartments were separated among the eggshell, the vitellus, the PVF and the embryo. The cuttlebone was then separated from the embryo flesh, dried at $65^{\circ} \mathrm{C}$ for $24 \mathrm{~h}$ and weighted.

Experiment 2: to follow the incorporation of ${ }^{45} \mathrm{Ca}$ in the juvenile cuttlebone, 10-days old juveniles were exposed to ${ }^{45} \mathrm{Ca}\left(25 \mathrm{kBq} \mathrm{L}^{-1}\right)$ after the transfer from bottles to tanks for a maximum of three weeks. The radioactive exposure procedure was carried out as described above (see Experiment 1). After 9 days of exposure, 5 to 12 19-days old juveniles were sampled in each condition to determine the radiotracer concentration in their cuttlebone. Juveniles were sampled, frozen at $-20^{\circ} \mathrm{C}$ and dried for one night at $65^{\circ} \mathrm{C}$. In order to individualize cuttlebones from flesh, dried juveniles bodies were individually dissolved with $8 \mathrm{~mL}$ of $\mathrm{NaOH}(2 \mathrm{~N})$, heated at $40^{\circ} \mathrm{C}$ (5 hours) and continuously agitated until cuttlebones were completely free from flesh. Cuttlebones were collected, rinsed into clear distilled water and dried $\left(24 \mathrm{~h}\right.$ at $\left.65^{\circ} \mathrm{C}\right)$ before dry mass was measured.

Radioactive sample treatment: Radioactive isolated calcareous structures were dissolved adding $300 \mu \mathrm{L}$ of hydrochloric acid $(\mathrm{HCl}, 37 \%)$ at $80^{\circ} \mathrm{C}$. After evaporation, the residues were dissolved in $1 \mathrm{~mL}$ of distilled water. Biological and seawater samples were counted after adding $10 \mathrm{~mL}$ of scintillation liquid, Ultima GoldTM XR (Perkin Elmer). Emissions were measured with a liquid 
scintillation analyzer (Tri-Carb, Packarb 1600 TR or Perkin Elmer 2900 TR) calibrated with an appropriate standard for each counting that was used. Counting times were adapted to obtain relative propagated errors less than $5 \%$ (from $10 \mathrm{~min}$ to $24 \mathrm{~h}$ ). Corrections for the physical half-life time and background noise were done in order to determine the ${ }^{45} \mathrm{Ca}$ concentrations at the sampling time (Bq). Uptake of ${ }^{45} \mathrm{Ca}$ in the cuttlebone was expressed as the amount of $\mathrm{Ca}$ incorporated $\left(\mathrm{Q}_{\mathrm{Ca}}\right.$, in $\mu \mathrm{mol}{ }^{45} \mathrm{Ca}$ cuttlebone ${ }^{-1}$ ) according to Martin et al. (2011) and following the equation:

$\mathrm{Q}_{\mathrm{Ca}}=\left[\left(\mathrm{A}_{\mathrm{cut}} / \mathrm{A}_{\mathrm{sw}}\right) \times \mathrm{C}_{\mathrm{sw}}\right] \times 10^{3}$

where $\mathrm{A}_{\text {cut }}$ is the total ${ }^{45} \mathrm{Ca}$ activity in each cuttlebone (in $\mathrm{Bq}$ ), $\mathrm{A}_{\mathrm{sw}}$ is the time-integrated activity (in $\mathrm{Bq}^{-1}$ ) in seawater during the time of exposure and $\mathrm{C}_{\mathrm{sw}}$ is the total $\mathrm{Ca}$ concentration in Mediterranean seawater $\left(0.0114 \mathrm{mmol} \mathrm{g}^{-1}\right)$.

\section{Data analyses:}

Results are presented for both the end of embryonic development (stage 30) and day 19 of juvenile life and are given as mean \pm SD. Statistical analyses were conducted using the software $\mathrm{R}(\mathrm{R}$ Development Core Team, 2008). To test the effect of $\mathrm{pH}$ and temperature treatments and their interaction, two-ways ANOVAs were performed. Prior to analyses, the data was checked for normality distribution and homogeneity of variances. When necessary, post-hoc test and interaction plots were used to determine the factors' interactions. All the test decisions were taken at a threshold of $\alpha=0.05$.

\section{RESULTS}

Seawater carbonate chemistry conditions: seawater carbonate chemistry parameters in the different $\mathrm{pH}$ and temperature conditions are reported in Table 1. Mean $\mathrm{A}_{\mathrm{T}}$ of the seawater was $2.597 \pm 0.012$ mmol kg$~^{-1}$ and $2.549 \pm 0.065 \mathrm{mmol} \mathrm{kg}^{-1}$ in the egg and juvenile experiments, respectively; in both experiments, $A_{T}$ changed by less than $0.030 \mathrm{mmol} \mathrm{kg}^{-1}$ between two seawater renewals. Seawater temperature and $\mathrm{pH}$ were stable over the experiments, showing variations lower than $2.5 \%$ from the mean of each measured parameter. Both eggs and juveniles were maintained at $p \mathrm{CO}_{2}$ of ca. 380 $\mu$ atm $\left(\mathrm{pH}_{\mathrm{T}}=8.09\right)$, ca. $750 \mu \mathrm{atm}\left(\mathrm{pH}_{\mathrm{T}}=7.84\right)$ and ca. $1430 \mu \mathrm{atm}\left(\mathrm{pH}_{\mathrm{T}}=7.60\right)$ irrespective of the temperature $\left(16\right.$ or $\left.19^{\circ} \mathrm{C}\right)$, consistently with the actual and predicted $\mathrm{pH}$ values for the end of the century (IPCC 2007). In all experimental conditions, eggs and juveniles were reared in supersaturated seawater with respect to aragonite $\left(\Omega_{\mathrm{ar}}>1.15\right.$; Table 1$)$. 
PVF abiotic conditions (Experiment 2): the egg development duration was logically shortened by temperature increase, and hatchling delay caused by increasing $p \mathrm{CO}_{2}$ was not observed in our experimental conditions (stage 30 reached 65 days and 47 days after spawning, at respectively $16^{\circ} \mathrm{C}$ and $19^{\circ} \mathrm{C}$, irrespectively of the $p \mathrm{CO}_{2}$ treatment). The embryos develop inside the protective eggshell, bathing in the PVF which abiotic conditions (i.e. carbonate chemistry parameters and $p \mathrm{O}_{2}$ ) were determined at the end of the development (stage 30). At this stage, $\mathrm{PVF} p \mathrm{O}_{2}$ was very low with $\sim 25 \%$ of air saturation, all conditions merged (Fig. 2). At $16^{\circ} \mathrm{C}$, the $\mathrm{PVF} p \mathrm{O}_{2}$ was $25.28 \pm$ $2.95 \%$ vs. $23.73 \pm 2.45 \%$ air sat. at $19^{\circ} \mathrm{C}$, revealing a slightly but significantly higher oxygen consumption of the embryo at warmer temperature (Table 2; $P=0.02$ ), especially visible in control $\mathrm{pH}$ conditions (8.10: $27.1 \pm 2.4 \%$ at $16^{\circ} \mathrm{C}$ vs. $22.9 \pm 3.0 \%$ air sat. at $\left.19^{\circ} \mathrm{C}\right)$. Seawater $\mathrm{pH}$ did not significantly influence PVF $p \mathrm{O}_{2}$ in eggs close to hatching $(P=0.285)$ but had a significant combined effect with the temperature $(P=0.012)$, revealing a slender decrease of the $\mathrm{PVF} p \mathrm{O}_{2}$ with decreasing $\mathrm{pH}$ only at $16^{\circ} \mathrm{C}(27.1 \pm 2.4 \%, 25.4 \pm 3.1 \%$ and $23.4 \pm 2.2 \%$ air sat. in $\mathrm{pH}$ conditions of respectively $8.10,7.85$ and 7.60$)$.

At stage 30, the embryo bathed in an environment with lower $\mathrm{pH}$ than that of the surrounding seawater $\left(7.05 \leq \mathrm{PVF}_{\mathrm{pH}} \mathrm{Sws} \leq 7.51\right.$ units, Fig. 2). The lowest values were reached in eggs exposed to $\mathrm{pH} 7.60$ treatment $\left(\mathrm{PVF} \mathrm{pH}_{\mathrm{Sws}}=7.07 \pm 0.01\right.$ at $16^{\circ} \mathrm{C}$ and $7.10 \pm 0.03$ at $\left.19^{\circ} \mathrm{C}\right)$. Besides, $\mathrm{PVF} \mathrm{pH}$ was significantly lower at $16^{\circ} \mathrm{C}\left(\mathrm{pH}_{\mathrm{SwS}}=7.07 \pm 0.01,7.21 \pm 0.02\right.$ and $7.35 \pm 0.03$ units, in $\mathrm{pH}$ treatments of $8.10,7.85$ and 7.60 respectively) than at $19^{\circ} \mathrm{C}(7.10 \pm 0.03,7.22 \pm 0.03$ and, $7.45 \pm$ 0.03 units, respectively, $P<0.001$, Table 2).

In control $\mathrm{pH}$ condition, embryos were exposed to a ca. 5 to 6 times higher $p \mathrm{CO}_{2}$ compared to external conditions, whatever the temperature (PVF vs. seawater: $2311 \mu \mathrm{atm}$ vs. $376 \mu \mathrm{atm}$ at $16^{\circ} \mathrm{C}$ and $1822 \mu \mathrm{atm}$ vs. $370 \mu \mathrm{atm}$ at $19^{\circ} \mathrm{C}$ ). PVF $p \mathrm{CO}_{2}$ increased with lower seawater pH (Fig. 2), reaching maximum values of ca. $4700 \mu \mathrm{atm}$ in the lowest $\mathrm{pH}$ treatment (i.e. seawater $p \mathrm{CO}_{2}$ of ca.1400 $\mu \mathrm{atm}) . \mathrm{CO}_{2}$ gradient between PVF and seawater $\left(\Delta p \mathrm{CO}_{2}\right.$ - i.e. $p \mathrm{CO}_{2}$ inside the PVF minus seawater $p \mathrm{CO}_{2}$ ) thus increased with higher seawater $p \mathrm{CO}_{2}$ (Table $2, P<0.001$ ). Respective $\Delta p \mathrm{CO}_{2}$ values in $\mathrm{pH}$ treatments of 8.10, 7.85 and 7.60 were of $1863 \pm 142,2391 \pm 192$ and $2852 \pm 178$ $\mu \mathrm{atm}$ at $16^{\circ} \mathrm{C}$ and $1458 \pm 164,2217 \pm 231$ and $2794 \pm 249 \mu \mathrm{atm}$ at $19^{\circ} \mathrm{C}$. The $p \mathrm{CO}_{2}$ gradient and hence the difference of $p \mathrm{CO}_{2}$ between the exterior and the interior of the egg, was also diminished under warmer treatments $(P<0.001)$. Alongside with the extremely high $\mathrm{PVF} p \mathrm{CO}_{2}$, the PVF was always under-saturated with respect to aragonite, even under control conditions (Fig. 2: $\Omega_{\mathrm{ar}}=0.644$ \pm 0.038 units at $16^{\circ} \mathrm{C}$ and $0.886 \pm 0.039$ units at $19^{\circ} \mathrm{C}$ ). As expected, the $\Omega_{\text {ar values dropped with }}$ decreasing $\mathrm{pH}$ (Table $2, P<0.001$ ), leading to extremely low values in seawater $\mathrm{pH}$ treatment of $7.60\left(\Omega_{\mathrm{ar}}=0.335 \pm 0.011\right.$ units at $16^{\circ} \mathrm{C}$ and $\Omega_{\mathrm{ar}}=0.418 \pm 0.032$ units at $\left.19^{\circ} \mathrm{C}\right)$. Our results revealed 
an interaction of both seawater $\mathrm{pH}$ and temperature with respect to PVF carbonate chemistry. Acidification rapidly worsen conditions advantageous to calcium precipitation in the embryonic fluid $\left(\Omega_{\text {ar PVF }}=0.771 \pm 0.130,0.487 \pm 0.062\right.$ and $0.372 \pm 0.047$ units at respectively $8.10,7.85$ and 7.60), while this effect appeared counterbalanced by seawater warming (Table 2: $\mathrm{pH}_{\mathrm{PVF}}: P<0.001$; $p \mathrm{CO}_{2 \mathrm{PVF}}: P<0.01 ; \Omega_{\mathrm{ar} \text { PVF }} P<0.001 ; \Delta p \mathrm{CO}_{2}$ PVF: $\left.P<0.05\right)$ leading to more under-saturated fluids at low temperature.

Embryonic and juvenile development: the egg swelling was followed in Experiment 1 (2008) and 2 (2009) by measuring the whole egg weight. Because egg size is a female-dependent property, the egg weights were clearly different between the two experiments. However, it is noteworthy that egg weights within each group were affected by temperature at the end of development (Fig. 3; Table 2; $P<0.001$ for both years), with heavier eggs at $19^{\circ} \mathrm{C}$ than at $16^{\circ} \mathrm{C}$ (respectively $2.28 \pm 0.10 \mathrm{~g}$ vs. $1.71 \pm 0.16 \mathrm{~g}$ in 2008 and $3.69 \pm 0.33 \mathrm{~g}$ vs. $2.95 \pm 0.25 \mathrm{~g}$ in 2009). $\mathrm{pH}$ treatment also influenced significantly the egg weight $(P<0.001$ in 2008 and $P=0.007$ in 2009; Table 2) highlighting an enhanced egg swelling phenomenon under acidified conditions. This $\mathrm{pH}$ effect was however weaken at warmer temperature, with similar egg weights for all $\mathrm{pH}$ at $19^{\circ} \mathrm{C}$ (Fig. 3; Table 2: $P<$ 0.001 in 2008 and $P=0.028$ in 2009).

At the end of the development (Experiment 1), the whole body dry weight of the embryo was only affected by the temperature treatment $\left(P<0.001\right.$; Table 3). Embryos raised at $16^{\circ} \mathrm{C}$ during 61 days were significantly heavier than those that developed at $19^{\circ} \mathrm{C}$ during 42 days (Fig. $4 ; 32.39 \pm 1.38$ mg vs. $26.30 \pm 1.65 \mathrm{mg}$ respectively). Hatching success has not been significantly affected by treatments $(<5 \%$ of eggs were undeveloped, as usually observed in similar conditions). Survival rates of juveniles reared during the Experiment 2 was $>90 \%$ in all conditions during the first 3 weeks of incubation. The health of animal strongly decreased posterior to this date and high mortality was observed along the following days ( $~ 80 \%$ mortality reached by 36 and 30 days posthatching in 16 and $19^{\circ} \mathrm{C}$ treatments respectively). Therefore, we focused on measures of ${ }^{45} \mathrm{Ca}$ uptake collected in healthy juveniles (showing hunting activities when fed, standing on the bottom of the tank) sampled after 19 days of incubation in the six treatments. According to these data, neither temperature nor $\mathrm{pH}$ had an effect on body dry weight after 19 days of incubation (see above: 10 days of maintenance post-hatching and 9 days of exposure; Fig. 4).

Cuttlebone growth and calcification: at the end of development, the weight of embryo's cuttlebone was not significantly affected by the $\mathrm{pH}$ treatment (Experiment $1, P=0.59$; Table 3 and Fig. 4) but was heavier in animals maintained at $19^{\circ} \mathrm{C}$ compared to $16^{\circ} \mathrm{C}(3.24 \pm 1.28 \mathrm{mg}$ vs. $1.43 \pm 0.30 \mathrm{mg}$ respectively; $P<0.001)$. In 19 -days old juveniles, the cuttlebones were slightly heavier at $19^{\circ} \mathrm{C}$ than at $16^{\circ} \mathrm{C}$ (Experiment 2, $3.66 \pm 0.86 \mathrm{mg}$ vs. $3.00 \pm 0.44 \mathrm{mg}$ respectively; $P<0.05$ ). Cuttlefish 
calcification was assessed through ${ }^{45} \mathrm{Ca}$ incorporation in cuttlebones both during the whole embryonic development (42 or 61 days) and 9 days of juvenile life. This difference of incubation time explains the contrasting quantity of calcium $\left(\mathrm{Q}_{\mathrm{Ca}}\right.$ : in $\left.\mu \mathrm{mol}\right)$ precipitated in embryo and juvenile calcareous structure (Fig. 5). Temperature also had an effect on ${ }^{45} \mathrm{Ca}$ incorporation, however, only at the embryonic stage: a seawater warming of $3^{\circ} \mathrm{C}$ reduced $\mathrm{Q}_{\mathrm{Ca}}$ by a factor of 1.6 irrespective of $\mathrm{pH}$ treatment (Fig. 5; $P<0.001$ ). Comparisons within each experiment indicated that accumulation of $\mathrm{CaCO}_{3}\left(\mathrm{Q}_{\mathrm{Ca}}\right)$ was greater with decreasing $\mathrm{pH}$ both in embryo and juvenile stages (Fig. 5; $P<$ 0.001). The lowest $\mathrm{pH}$ treatment led to an increase of calcium incorporation in cuttlebone from ca. $17 \%$ in embryo to up $80 \%$ in juvenile in our experimental conditions.

\section{DISCUSSION}

According to our results, a decrease of seawater $\mathrm{pH}$ by 0.25 to 0.50 units, as expected in average for the end of the century in global oceans, would increase the accumulation of calcium in the internal calcareous structure by $17 \%$ to $80 \%$ in embryonic and juvenile cuttlefish respectively. This study corroborates with the observation of Gutowska et al. (2010b) where cuttlebones of Sepia officinalis juveniles displayed a significant increase in $\mathrm{CaCO}_{3}$ mass (hypercalcification) under very high $p \mathrm{CO}_{2}$ ( $\sim 6000 \mu$ atm for 40 days). Here, using ${ }^{45} \mathrm{Ca} \beta$-emitting radiotracer, a very sensitive nuclear detection method that allows for calcification rate estimation in early life stages (Fabry and Balch 2010), we demonstrate that such hypercalcification also occurs under realistic scenarios of increased temperature and $p \mathrm{CO}_{2}$ in early life stages of Sepia.

In cephalopods, the requirements in essential elements are poorly known and only few studies have examined the elemental content of early stages (Craig and Overnell 2003, Villanueva and Bustamante 2006, Miramand et al. 2006). Calcium reserves needed for metabolic processes could be contained in the rich yolk of the cuttlefish egg (Boletzky 1974, 1989; e.g. Lacoue-Labarthe et al. 2009). In the octopod Octopus vulgaris however, calcium concentration increases during the oocyte development, suggesting that this essential element could be obtained from seawater intake (Villanueva and Bustamante 2006). It has been previously demonstrated that the eggshell displays a selective permeability to dissolved trace elements, independently of their essential or non-essential character (Bustamante et al. 2002, 2004, 2006, Lacoue-Labarthe et al. 2008, 2009, 2010a), and that changes in seawater $p \mathrm{CO}_{2}$ conditions could affect these properties (Lacoue-Labarthe et al. 2009). In

this study, it is worth noting that, whatever the treatment, ${ }^{45} \mathrm{Ca}$ was detected in embryos' cuttlebones revealing that 1) the eggshell is permeable to calcium and 2) the cuttlebone formation is dependent on calcium uptake from seawater. If external seawater is the only source of calcium, approximately 
$2.7 \mathrm{~mL}$ of seawater $\left(\left[\mathrm{Ca}^{2+}\right]=411 \mathrm{mg} \mathrm{LSW}^{-1}\right)$ would need to be depleted of calcium in order to build a cuttlebone at the end of development at $19^{\circ} \mathrm{C}$ (dry weight $=3.0 \mathrm{mg}$, composed of $95 \% \mathrm{CaCO}_{3}$ ).

Both embryos and juveniles hypercalcified when exposed to elevated $p \mathrm{CO}_{2}$, although the surrounding medium became less favorable to $\mathrm{CaCO}_{3}$ precipitation (i.e. decreasing $\Omega_{\mathrm{ar}}$ ). Numerous studies on bivalve molluscs showed reduced rates of calcification in response to ocean acidification (e.g. Miller et al. 2009; Thomsen et al. 2010). Marine organisms display a species-specific ability to calcify (Ries et al. 2009, Findlay et al. 2011), probably linked to their ability to maintain favorable chemical condition for $\mathrm{CaCO}_{3}$ precipitation at the calcification site when exposed to high $p \mathrm{CO}_{2}$ (e.g. Venn et al. 2011). Protective organic layers covering the calcareous structure are a key to determine species vulnerability against corrosive seawater that can lead to external $\mathrm{CaCO}_{3}$ dissolution (Tunnicliffe et al. 2009, Ries et al. 2009; Rodolfo-Metalpa et al. 2010, Thomsen et al. 2010). The cuttlefish is a unique mollusc model as it is characterized by a fully internal calcareous structure. This latter is bathed in extracellular fluids with their particular controlled carbonate chemistry and surrounded by the shell forming an epithelium (Appellöf 1893). Similarly, hypercalcification has also been observed in the internal otoliths of fish (Checkley, 2009), a structure bathing inside a fluid chamber and regulating fish equilibrium. Shiao et al. (2005) postulate that calcification conditions are maintained around the otolith by the ion-transporters discovered on the external membrane. The specificity of an internal structure in S. officinalis could thus be one reason for the ability to calcify even under the drastic abiotic conditions within the PVF as observed in this study.

The higher calcification observed under acidified conditions of both embryos and juveniles should be considered in relation to the abiotic conditions in which the animals developed, i.e. the PVF vs. seawater. Within the egg at the end of development, PVF $p \mathrm{O}_{2}$ was low due to the metabolic requirements of the growing embryo, as previously demonstrated (Cronin and Seymour 2000; Gutowska and Melzner 2009). In turn, aerobic metabolism produces $\mathrm{CO}_{2}$, ultimately resulting in a very high PVF $p \mathrm{CO}_{2}$, even in ambient conditions (Gutowska and Melzner 2009; this study). PVF $p \mathrm{CO}_{2}$ was affected by increasing seawater $p \mathrm{CO}_{2}$, with $\mathrm{PVF} p \mathrm{CO}_{2}$ rising up to ca. $4000 \mu$ atm when eggs were incubated at a seawater $p \mathrm{CO}_{2}$ of ca. $1400 \mu \mathrm{atm}$ (see Fig. 2). This additive effect of ocean acidification on the PVF hypercapnic conditions is necessary to maintain rates of $\mathrm{CO}_{2}$ excretion from the PVF to the seawater (Hu et al. 2011a). Diffusive flux of metabolic $\mathrm{CO}_{2}$ out of the egg $\left(\mathrm{MCO}_{2}\right)$ is proportional to the surface of the eggshell (A), the $p \mathrm{CO}_{2}$ gradient between PVF and seawater $\left(\triangle p \mathrm{CO}_{2}\right)$ and inversely proportional to the thickness $(\mathrm{d})$ of the eggshell. It also depends on the specific material properties of the barrier (Krogh's gas diffusion coefficient, K):

$$
\mathrm{MCO}_{2}=\Delta p \mathrm{CO}_{2} \times \mathrm{A} / \mathrm{d} \times \mathrm{K}
$$


While maintenance of the $\Delta p \mathrm{CO}_{2}$ seems to be crucial for cuttlefish embryos exposed to elevated seawater $p \mathrm{CO}_{2}$, our work also suggests that other responses are facilitating $\mathrm{CO}_{2}\left(\mathrm{O}_{2}\right)$ diffusion from the egg to the seawater (and vice versa). A temperature increase of $3^{\circ} \mathrm{C}$ induces an egg weight increase of $c a$. 20-30\%, resulting in an estimated egg surface area increase of 15-20\% (LacoueLabarthe et al. 2009; this study). Although the mechanism controlling the swelling process is not fully understood (see Lacoue-Labarthe et al. 2009), the osmotic gradient driven water entry in the perivitelline space (de Leersnyder and Lemaire 1972) might be closely coupled to physiological processes of the developing embryo. The enhanced swelling of the egg, as shown in Fig. 3, directly increases the surface area (A) of the eggshell and reduces its thickness (d) (see Cronin and Seymour 2000). This process therefore contributes to facilitate $\mathrm{CO}_{2}$ exchanges in order to maintain low PVF $p \mathrm{CO}_{2}$, especially when metabolic rates are increased with elevated temperature and $p \mathrm{CO}_{2}(\mathrm{Melzner}$ et al. 2006). For example, at $\mathrm{pH} 8.10$, the $\mathrm{PVF} p \mathrm{CO}_{2}$ was lower at $19^{\circ} \mathrm{C}$ than at $16^{\circ} \mathrm{C}$ whereas a higher value would be expected at warmer temperature, due to increased metabolic activities. We postulate that the enhanced egg swelling at $19^{\circ} \mathrm{C}$ and the subsequent increased surface / reduced thickness of the eggshell allows a $\Delta p \mathrm{CO}_{2}$ decrease and hence a lower PVF $p \mathrm{CO}_{2}$. This higher gas exchange at higher temperature could also explain the slightly lower $p \mathrm{O}_{2}$ at $19^{\circ} \mathrm{C}$ than at $16^{\circ} \mathrm{C}$ at the end of development. Nevertheless, the effect of $\mathrm{pCO}_{2}$ on egg volume was weaken at high temperature, suggesting that swelling plasticity could be limited and that, at the end of development, the egg capsule probably reached its maximum stretching capacity at $19^{\circ} \mathrm{C}$, irrespective of the $\mathrm{pH}$ treatment. Under such conditions, additive effects of $p \mathrm{CO}_{2}$ and temperature might be hidden by structural limitation of the eggshell.

These adverse abiotic conditions in the PVF have implications regarding 1) the calcification capacities of the embryo and 2) the developmental conditions for the subsequent juvenile life. First, despite the under-saturation of the PVF, even under normal $\mathrm{pH}$ conditions $\left(0.58 \leq \Omega_{\mathrm{ar}} \leq 0.96\right)$, embryos are able to precipitate aragonite. They furthermore increased calcium accumulation in a PVF medium extremely under-saturated with $\mathrm{CaCO}_{3}\left(0.32 \leq \Omega_{\mathrm{ar}} \leq 0.47\right.$ when seawater $\left.\mathrm{pH}=7.60\right)$. In juvenile animals exposed to $6000 \mu \mathrm{atm}$ of $p \mathrm{CO}_{2}$, the higher rates of calcification were hypothetically linked to their efficient acid-base regulation capacities (Gutowska et al. 2010a). More precisely, cuttlefish were observed to rapidly increase blood bicarbonate $\left(\mathrm{HCO}_{3}{ }^{-}\right)$ concentrations from 3.3 to $10.4 \mathrm{mM}$ in the blood to compensate hypercapnia-induced extracellular acidosis (Gutowska et al. 2010b). Increases in extracellular $\left[\mathrm{HCO}_{3}{ }^{-}\right]$raises the calcium carbonate saturation state in extracellular fluids, potentially facilitating calcium precipitation at the site of biomineralization, or increasing $\mathrm{HCO}_{3}{ }^{-}$transport into calcifying epithelial cells (Gutowska et al. 2010a). Such process could also be at work in embryos since Hu et al. (2010, 2011a) demonstrated that the gills of late cuttlefish embryos are characterized by an active ion regulatory machinery 
capable of acid-base regulation. In addition, $\mathrm{Hu}$ et al. (2011b) could establish the presence of ionocytes on skin and yolk epithelium even in earlier embryonic stages that lack gills. These authors revealed net proton excretory fluxes from the embryo to the surrounding medium, suggesting that even early cephalopod embryos are able to regulate body fluid $\mathrm{pH}$ by means of bicarbonate accumulation / net proton excretion. Hypermineralization was observed predominantly in species that are characterized by efficient blood / haemolymph accumulation capacities (crustacea: Ries et al. 2009, teleost fish: Checkley et al. 2009, Munday et al. 2011). In echinoderms, hypercalcification under acidified conditions has only been noted in adults (Wood et al. 2008 and Ries et al. 2009), stage at which abilities to regulate the internal coelomic fluid $\mathrm{pH}$ by modulating bicarbonate accumulation were observed (sea urchin: Stumpp et al. 2012). In this same group (Beniash et al. 1997, 1999, Politi et al. 2004) and recently in bivalves (Weiss et al. 2002, Jacob et al. 2011), it was shown that the initial stages of calcification are intracellular processes: an amorphous calcium carbonate (ACC) precursor phase is formed in vesicles and later exocytosed to be incorporated into the skeleton (see Addadi et al. 2006 for a review of current concepts). It is not unlikely that elevated blood bicarbonate concentrations, as encountered during hypercapnia in cuttlefish, increase the rates of import of this substrate for biomineralization into calcifying epithelial cells: ACC formation and calcification in general could be increased this way. The mechanisms behind cuttlefish calcification will be a beneficial topic for further research.

The ability of cuttlefish embryos to calcify under extremely high seawater $p \mathrm{CO}_{2}$ raises the question of whether this high physiological performance is associated with increased metabolic costs. Recent studies have measured increased metabolic costs associated with experimentally elevated seawater $p \mathrm{CO}_{2}$ (Wood et al. 2008; Thomsen and Melzner 2010; Stumpp et al. 2011), more particularly suggesting energetic trade-offs that impact growth rate - a situation similar to that encountered in many echinoderm larval stages (see Dupont et al. 2010 for a review, Stumpp et al 2011). Active compensation for acidosis and hypercapnia did not induce measureable additive costs in subadult $S$. officinalis exposed to a $p \mathrm{CO}_{2}$ of $6000 \mu \mathrm{atm}$ (Gutowska et al. 2008). However, PVF hypercapnia led to a decrease of embryo weight and a delay in embryonic development when eggs were incubated at $3700 \mu \mathrm{atm}$ (Hu et al. 2011a) or at $1500 \mu \mathrm{atm}$ (Lacoue-Labarthe et al. 2009). In this study, the $p \mathrm{CO}_{2}$ did not significantly impact embryos weight before hatching (Fig. 4 and Table 3) contrasting with previous observations (Lacoue-Labarthe et al. 2009a; Hu et al. 2011a). Without obvious explanation, these results have to be considered with caution and would need confirmation in the future. Nevertheless, the lowest weight value, recorded at the highest temperature and $p \mathrm{CO}_{2}$, suggests synergetic effects of both parameters as previously demonstrated in corals and molluscs (e.g. Rodolfo-Metalpa et al. 2011) and that combined ocean acidification and warming may reduce the efficiency of yolk utilization through an energy budget modulation (Pörtner 2008). Therefore, 
on one side, under elevated seawater $p \mathrm{CO}_{2}$, combined hypoxia and hypercapnia in the PVF would slow down the developmental rate, explaining the delay in hatching time observed by $\mathrm{Hu}$ et al. (2011a), and on the other side, extreme seawater and PVF $p \mathrm{CO}_{2}$ would lead to an increased allocation of energy to acid-base and other cellular homeostatic processes (including ion movements associated with ACC formation for example) at the expense of animal growth. Enhanced egg swelling with increasing hypercapnia and temperature could as well worsen the energy loss for the embryo if the osmotic gradient maintenance between the PVF and seawater required active metabolic processes (Gomi et al. 1986).

The hatching event constitutes a harsh shock for the animal, as the embryo leaves the medium protecting it against direct predation and microbial attacks (Barbieri et al. 1997); however, the juvenile encounters a higher $\mathrm{pH}$ and lower $\mathrm{pCO}_{2}$, resulting in a lower requirement for blood $\mathrm{pH}$ regulation. Still, ${ }^{45} \mathrm{Ca}$ incorporation in the cuttlebone was found to be increased even in juveniles under acidified conditions, indicating that similar mechanisms as described must be operative in juveniles as well. In contrary to Gutowska et al. (2010b), we were not able to measure a difference in cuttlebone mass in response to $p \mathrm{CO}_{2}$ or temperature, however our animals were younger and smaller. The cuttlebone is mainly composed of $\mathrm{CaCO}_{3}$ (92 to $95 \%$ mass) embedded in an organic matrix, giving the organ structure; therefore, in this study, it is not possible to infer conclusion on the impact of the experimental treatments on the organic matrix. Nevertheless, it should be mentioned that a high seawater $p \mathrm{CO}_{2}$ could modify the cuttlebone size, its internal structure, its organization or composition, resulting in an increase of calcium incorporation but no alteration of the weight. For example, under acidified conditions, along with 20-55\% increase in the cuttlebone mass, Gutowska et al. (2010b) observed a strong increase in the number of shell-chambers constituting the cuttlebone, including an increase in the number of $\mathrm{CaCO}_{3}$ structure such as pillars and walls. This last study also demonstrated that the mass of the non-acid-soluble organic matrix (or chitin), was significantly decreased under high $p \mathrm{CO}_{2}$. In other words: even if cuttlebones were heavier, organic material synthesis in the cuttlebone was decreased. Possibly, and in contrast to calcium carbonate precipitation, synthesis of organic components is complex and energetically costly (Palmer 1992). In conclusion, both higher calcium and lower chitin incorporation could result in altering cuttlebone properties like its buoyancy, by increasing its density, or implosion resistance properties (Sherrard 2000). Further studies should be carried out to determine the consequences of enhanced calcification under increased $p \mathrm{CO}_{2}$ in the cuttlefish early life stages on the microstructure of the cuttlebone and on the animal swimming abilities.

The results of this study demonstrate the particularities of the response to acidification in both in embryos and juveniles cuttlefish, in comparison to other invertebrates. Calcification processes 
under elevated $\mathrm{pCO}_{2}$ in cephalopods need to be better characterized in order to clarify the mechanisms leading to hypercalcification in this group. Although the combined effects of ocean acidification and temperature did not decrease calcium accumulation during the formation of the calcareous endoskeleton in S. officinalis embryos and juveniles, the functional properties of the cuttlebone as buoyancy device could be affected. The effect of raised $p \mathrm{CO}_{2}$ should be investigated on the animal entire life cycle considering possible carry-over effects (e.g. Parker et al. 2012, Dupont et al. 2012) and not only from the calcification point of view. Linked to buoyancy abilities, further studies on feeding behavior under projected scenarios of future environmental change would be required in order to assess $\mathrm{CO}_{2}$ impacts on population dynamics of the cuttlefish S. officinalis.

\section{ACKNOWLEDGMENTS}

Authors thank the reviewers and the editor of Marine Biology for their comments that strongly improved this paper. The International Atomic Energy Agency is grateful to the Government of the Principality of Monaco for the support provided to its Environment Laboratories. This work was supported by the IAEA. This work is a contribution to the "European Project on Ocean Acidification" (EPOCA) which received funding from the European Community's Seventh Framework Programme (FP7/2007-2013) under grant agreement no. 211384. Ms. André and Eric Rinaldi of Monaco are thanked for the collection of Sepia specimens. Mr Antoine and Mrs José Lacoue-Labarthe are thanked for providing juveniles of crabs and shrimps. 


\section{REFERENCES}

Addadi L, Joester D, Nudelman F, Weiner S (2006) Mollusk shell formation: A source of new concepts for understanding biomineralization processes. Chem Eur J 12:980-987. doi: 10.1002/chem.200500980

Appellöf A (1893) Die Schalen von Sepia, Spirula, and Nautilus. Studien über den Bau und das Wachstum. Kongl Svenska Vetensk Acad Handl 25:1-106. ISSN 0023-5377

Barbieri E, Barry K, Child A, Wainwright N (1997) Antimicrobial activity in the microbial community of the accessory nidamental gland and egg cases of Loligo pealei (Cephalopoda: Loliginidae). Biol Bull 193(2):275-276

Bégovic M, Copin-Montégut C (2002) Processes controlling annual variations in the partial pressure of $\mathrm{CO}_{2}$ in surface waters of the central northwestern Mediterranean Sea (Dyfamed site). Deep-Sea Res PT II 49:2031-2047

Beniash E, Aizenberg J, Addadi L, Weiner S (1997) Amorphous calcium carbonate transforms into calcite during sea urchin larval spicule growth. Proc Roy Soc B 264:461-465. doi: 10.1098/rspb.1997.0066

Beniash E, Addadi L, Weiner S (1999) Cellular control over spicule formation in sea urchin embryos: A structural approach. J Struct Biol, 125, 50-62. doi: 10.1006/jsbi.1998.4081

Bijma J, Honisch B, Zeebe RE (2002) The impact of the ocean carbonate chemistry on living foraminiferal shell weight: Comment on "Carbonate ion concentration in glacial-age deep waters of the Carribbean Sea' by W. S. Broecker and E. Clark, Geochem. Geophys. Geosyst. 3(11):1064. doi:10.1029/2002GC000388

Birchall JD, Thomas NL (1983) On the architecture and function of cuttlefish bone. J Mater Sci 18:2081-2086. doi: 10.1007/BF00555001

Blackford JC (2010). Predicting the impacts of ocean acidification: Challenges from an ecosystem perspective. J Marine Syst 81(1-2):12-18. doi: 10.1016/j.jmarsys.2009.12.016

Boletzky SV (1974) The "larvae" of Cephalopoda: a review. Thalassia Jugoslavica 10:45-76

Boletzky SV (1983) Sepia officinalis cephalopod life cycles species account. In: Boyle PR (ed) Cephalopod Life Cycle. Academic Press, London pp 31-52

Boletzky SV (1986) Encapsulation of cephalopod embryos: a search for functional correlations. Am Malacol Bull 4:217-227

Boletzky SV (1989) Recent studies on spawning, embryonic development, and hatching in the Cephalopoda. Adv Mar Biol 6:86-109

Boletzky SV (2003) Biology of early life stages in cephalopod molluscs. Adv in Mar Biol 44:143203. doi: 10.1016/S0065-2881(03)44003-0

Bustamante P, Cosson RP, Gallien I, Caurant F, Miramand P (2002) Cadmium detoxification processes in the digestive gland of cephalopods in relation to accumulated cadmium concentrations. Mar Environ Res 53:227-241. doi:10.1016/S0141-1136(01)00108-8

Bustamante P, Teyssié J, Danis B, Fowler SW, Miramand P, Cotret O (2004) Uptake, transfer and distribution of silver and cobalt in tissues of the common cuttlefish Sepia officinalis at different stages of its life cycle. Mar Ecol Prog Ser 269:185-195. doi: 10.3354/meps269185

Bustamante P, Teyssié J-L, Fowler SW, Warnau M (2006) Contrasting bioaccumulation and transport behaviour of two artificial radionuclides $\left({ }^{241} \mathrm{Am}\right.$ and $\left.{ }^{134} \mathrm{Cs}\right)$ in cuttlefish eggshell. Vie Milieu 56(2):153-156

Byrne M (2011) Impact of ocean warming and ocean acidification on marine invertebrate life history stages: Vulnerabilities and potential persistence in a changing ocean. Oceanogr Mar Biol Annu Rev 49:1-42

Checkley DM, Dickson AG, Takahashi M, Radich JA, Eisenkolb N, Asch R (2009) Elevated $\mathrm{CO}_{2}$ enhances otolith growth in young fish. Science 324:1683-1683. doi: 101126/science1169806S

Comeau S, Gattuso J-P, Nisumaa A-M, Orr J (2011) Impact of aragonite saturation state changes on migratory pteropods. Proc Roy Soc B. doi: 10.1098/rspb.2011.0910 
Craig S, Overnell J (2003) Metals in squid, Loligo forbesi, adults, eggs and hatchlings. No evidence for a role for $\mathrm{Cu}$ - or Zn-metallothionein. Comp Biochem Phys C 134(3):311-317. doi: 10.1016/S1532-0456(02)00274-0

Cronin ER, Seymour RS (2000) Respiration of the eggs of the giant cuttlefish Sepia apama. Mar Biol 136:863-870. doi: 10.1007/s002270000274

Denton EJ, Gilpin-Brown JB (1959) Buoyancy of the cuttlefish. Nature 184:1330-1331. doi:10.1038/1841330a0

Denton EJ, Gilpin-Brown JB (1961) The buoyancy of the cuttlefish, Sepia officinalis (L.). J Mar Biol Assoc UK 41:319-342. doi: 10.1017/S0025315400023948

Denton EJ, Gilpin-Brown JB, Howarth JV (1961) The osmotic mechanism of the cuttlebone. J Mar Biol Assoc UK 41:351-363. doi: 10.1017/S0025315400023961

Denton EJ, Taylor DW (1964) The composition of gas in the chambers of the cuttlebone of Sepia officinalis. J Mar Biol Assoc UK 44:203-207. doi: 10.1017/S0025315400024747

Dickson AG, Millero F (1987) A comparison of the equilibrium constants for the dissociation of carbonic acid in seawater media. Deep-Sea Res 34:1733-1743. doi: 10.1016/0198-0149(87)90021-5 Dickson AG, Sabine CL, Christian JR (2007) Guide to best practices for ocean $\mathrm{CO}_{2}$ measurements. PICES Spec Publ 3, 191pp

Dupont S, Thorndyke MC (2009) Impact of $\mathrm{CO}_{2}$-driven ocean acidification on invertebrates early life-history - What we know, what we need to know and what we can do? Biogeosci Discussions 6:3109-3131. doi:10.5194/bgd-6-3109-2009

Dupont S, Ortega-Martínez O, Thorndyke MC (2010) Impact of near-future ocean acidification on echinoderms. Ecotoxicology 19:449-62. doi: 10.1007/s10646-010-0463-6

Dupont S, Dorey N, Stumpp M, Melzner F, Thorndyke M (2012) Long term and trans life-cycle effects of exposure to ocean acidification in the green sea urchin Strongylocentrotus droebachiensis. Mar Biol. doi: 10.1007/s00227-012-1921-x

Fabry VJ, Balch WM (2010) Direct measurments of calcification rates in planktonic organisms. In: Riebesell U, Fabry VJ, Hanson L, Gattuso JP (eds) Guide for best practices in ocean acidification research and data reporting. Publications Office of the European Unit, Luxembourg, pp 201-212

Findlay HS, Wood HL, Kendall Ma, Spicer JI, Twitchett RJ, Widdicombe S (2011) Comparing the impact of high $\mathrm{CO}_{2}$ on calcium carbonate structures in different marine organisms. Mar Biol Res, 7:565-575

Forsythe JW, Lee P, Walsh L, Clark T (2002) The effects of crowding on growth of the European cuttlefish, Sepia officinalis (Linnaeus, 1758) reared at two temperatures. J Exp Mar Biol Ecol 269(2):173-185. doi:10.1016/S0022-0981(02)00006-0

Gazeau F, Gattuso JP, Dawber C, Pronker AE, Peene F, Peene J, Heip CHR, Middelburg JJ (2010) Effect of ocean acidification on the early life stages of the blue mussel Mytilus edulis. Biogeosciences 7:2051-2060. doi: 10.5194/bg-7-2051-2010

Gazeau F, Gattuso J-P, Greaves M, Elderfield H, Peene J, Heip CHR, Middelburg JJ (2011) Effect of carbonate chemistry alteration on the early embryonic development of the Pacific oyster (Crassostrea gigas). PLoS one 6:e23010. doi:10.1371/journal.pone.0023010

Gomi F, Masamich Y, Nakazawa T (1986) Swelling of egg during development of the cuttlefish, Sepiella japonica. Zool Sci 3(4):641-645

Gooding Ra, Harley CDG, Tang E (2009) Elevated water temperature and carbon dioxide concentration increase the growth of a keystone echinoderm. P Natl Acad Sci USA 106:9316-9321 Guerra A (2006) Ecology of Sepia officinalis. Vie milieu 56(2):97-107

Gutowska MA, Pörtner H-O, Melzner F (2008) Growth and calcification in the cephalopod Sepia officinalis under elevated seawater $p \mathrm{CO}_{2}$. Mar Ecol Prog Ser 373:303-309. doi: 10.3354/meps07782 Gutowska MA, Melzner F (2009) Abiotic conditions in cephalopod (Sepia officinalis) eggs: embryonic development at low $\mathrm{pH}$ and high $p \mathrm{CO}_{2}$. Mar Biol 156:515-519. doi: 10.1007/s00227008-1096-7 
Gutowska MA, Melzner F, Langenbuch M, Bock C, Claireaux G, PörtnerHO (2010a) Acid-base regulatory ability of the cephalopod (Sepia officinalis) in response to environmental hypercapnia. $\mathbf{J}$ Comp Physiol B 180:323-335. doi: 10.1007/s00360-009-0412-y

Gutowska MA, Melzner F, Pörtner H-O, Meier S (2010b) Cuttlebone calcification increases during exposure to elevated seawater $p \mathrm{CO}_{2}$ in the cephalopod Sepia officinalis. Mar Biol 157:1653-1663. doi: 10.1007/s00227-010-1438-0

Hoegh-Guldberg O, Mumby PJ, Hoote, AJ et al. (2007) Coral reefs under rapid climate change and ocean acidification. Science 318:1737-1742. doi: 10.1126/science.1152509

Hu MY, Sucré E, Charmantier-Daures M, Charmantier G, Lucassen M, Himmerkus N, Melzner F (2010) Localization of ion-regulatory epithelia in embryos and hatchlings of two cephalopods. Cell Tissue Res 339:571-83. doi: 10.1007/s00441-009-0921-8

Hu MY, Tseng Y-C, Stumpp M, Gutowska MA, Kiko R, Lucassen M, Melzner F (2011a) Elevated seawater $p \mathrm{CO}_{2}$ differentially affects branchial acid-base transporters over the course of development in the cephalopod Sepia officinalis. Am J Physiol 300:R1100-R1114. doi: 10.1152/ajpregu.00653.2010

Hu MY, Tseng Y-C, Lin L-Y, Chen P-Y, Charmantier-Daures M, Hwang P-P, Melzner F (2011b) New insights into ion regulation of cephalopod molluscs: a role of epidermal ionocytes in acid-base regulation during embryogenesis. Am J Physiol 301:R1700-R1709. doi: 10.1152/ajpregu.00107. 2011

IPCC (2007) Fourth Assessment Report of the Intergovernmental Panel on Climate Change. In: Solomon, S., D. Qin, M. Manning, Z. Chen, M. Marquis, K.B. Averyt, M.Tignor and H.L. Miller (eds.) Climate Change 2007. Cambridge University Press, Cambridge, United Kingdom and New York, NY, USA.

Jacob DE, Wirth R, Soldati AL, Wehrmeister U, Schreiber A (2011) Amorphous calcium carbonate in the shells of adult Unionoida. J Struct Biol 173:241-249. doi: 10.1016/j.jsb.2010.09.011

Kleypas JA, Feely RA, Fabry VJ, Langdon C, Sabine CL, Robbins LL (2006) Impacts of ocean acidification on coral reefs and other marine calcifiers: a guide for future research, report of a workshop held 18-20 April 2005, St Petersburg, FL, sponsored by NSF, NOAA, and the US Geological Survey http://wwwucaredu/communications/Final_acidificationpdf

Kroeker KJ, Kordas RL, Crim RN, Singh GG (2010) Review and Synthesis: Meta-analysis reveals negative yet variable effects of ocean acidification on marine organisms. Ecol Lett 13:1419-1434. doi: 10.1111/j.1461-0248.2010.01518.x

Kurihara $\mathrm{H}$ (2008) Effects of $\mathrm{CO}_{2}$-driven ocean acidification on the early developmental stages of invertebrates. Mar Ecol Prog Ser 373:275-284. doi: 10.3354/meps07802

Lacoue-Labarthe T, Warnau M, Oberhänsli F, Teyssié J-L, Koueta N, Bustamante P (2008a) Differential bioaccumulation behaviour of $\mathrm{Ag}$ and $\mathrm{Cd}$ during the early development of the cuttlefish Sepia officinalis. Aquat Toxicol 86:437-46. doi: 10.1016/j.aquatox.2007.12.005

Lacoue-Labarthe T, Martin S, Oberhänsli F, Teyssié J-L, Markich S, Jeffree R, Bustamante P (2009) Effects of increased $p \mathrm{CO}_{2}$ and temperature on trace element (Ag, $\mathrm{Cd}$ and $\mathrm{Zn}$ ) bioaccumulation in the eggs of the common cuttlefish, Sepia officinalis. Biogeosciences 6:2561-73. doi: 10.5194/bg-6-2561-2009

Lacoue-Labarthe T, Warnau M, Oberhänsli F, Teyssié JL, Bustamante P (2010a) Contrasting accumulation biokinetics and distribution of ${ }^{241} \mathrm{Am}, \mathrm{Co}, \mathrm{Cs}, \mathrm{Mn}$ and $\mathrm{Zn}$ during the whole development time of the eggs of the common cuttlefish, Sepia officinalis. J Exp Mar Biol Ecol 382:131-138. doi:10.1016/j.jembe.2009.10.008

Lacoue-Labarthe T, Le Bihan E, Borg D, Koueta N, Bustamante P (2010b) Variation of acid phosphatases and cathepsins activities in the cuttlefish (Sepia officinalis) eggs: specific activity and effects of Ag , Cd , Cu exposures. ICES J Marine Sci 7:1517-1523. doi: 10.1093/icesjms/fsq044 Lacoue-Labarthe T, Villanueva R, Rouleau C, Oberhänsli F, Teyssié J-L, Jeffree R, Bustamante P (2011a) Radioisotopes demonstrate the contrasting bioaccumulation capacities of heavy metals in embryonic stages of cephalopod species. Plos One 6(11):e27653. doi:10.1371/journal.pone.0027653 
Lacoue-Labarthe T, Réveillac E, Oberhänsli F, Teyssié JL, Jeffree R, Gattuso JP (2011b) Effects of ocean acidification on trace element accumulation in the early-life stages of squid Loligo vulgaris. Aquat Toxicol 105:166-76. doi: 10.1016/j.aquatox.2011.05.021

Langdon C, Atkinson MJ (2005) Effect of elevated $p \mathrm{CO}_{2}$ on photosynthesis and calcification of corals and interactions with seasonal change in temperature/irradiance and nutrient enrichment. $\mathbf{J}$ Geophys Res 110:C09S07. doi:10.1029/2004JC002576

Lavigne H, Gattuso J-P (2009) seacarb: seawater carbonate chemistry with R. R package version 2.4. http://CRAN.R-project.org/package=seacarb

Leersnyder M De, Lemaire J (1972) Sur la composition minérale du liquide périembryonnaire de l'oeuf de Sepia officinalis L. Cah Biol Mar 13:429-43

Lemaire J (1970) Table de développement embryonnaire de Sepia officinalis L (Mollusque Céphalopode). B Soc Zool Fr 95(4):773-782

Levitus S, Antonov J, Boyer T (2005) Warming of the world ocean, 1955-2003. Geophys Res Lett 32:L02604. doi:10.1029/2004GL021592

Lewis E, Wallace DWR (1998) Program Developed for $\mathrm{CO}_{2}$ System Calculations. ORNL/ CDIAC105. U.S. Dept. Energy, Oak Ridge, Tennessee. http://cdiac.ornl.gov

Martin S, Richier S, Pedrotti M-L, Dupont S, Castejon C, Gerakis Y, Kerros M-E, Oberhänsli F, Teyssié J-L, Jeffree R, Gattuso J-P (2011) Early development and molecular plasticity in the Mediterranean sea urchin Paracentrotus lividus exposed to $\mathrm{CO}_{2}$-driven acidification. The $\mathrm{J}$ Exp Biol 214:1357-68. doi: 10.1242/jeb.051169

Mehrbach C, Culberson CH, Hawley JE, Pytkowicz RM (1973) Measurement of the apparent dissociation constants of carbonic acid in seawater at atmospheric pressure. Limnol Oceanogr 18(6):897-907

Melzner F, Forsythe J, Lee P, Wood J, Piatowski U, Clemmesen C (2005) Estimating recent growth in the cuttlefish: are nucleic acid-based indicators for growth and condition the method of choice? $\mathrm{J}$ Exp Mar Biol Ecol 317:37-51. doi: 10.1016/j.jembe.2004.11.011

Melzner F, Bock C, Pörtner H-O (2006) Temperature-dependent oxygen extraction from the ventilatory current and the costs of ventilation in the cephalopod Sepia officinalis. J Comp Physiol B 176:607-621. doi: 10.1007/s00360-006-0084-9

Melzner F, Bock C, Pörtner H-O (2007) Allometry of thermal limitation in the cephalopod Sepia officinalis. Comp Biochem Phys A 146:149-54. doi: 10.1016/j.cbpa.2006.07.023

Melzner F, Gutowska MA, Langenbuch M, Dupont S, Lucassen M, Thorndyke MC, Bleich M, Pörtner H-O (2009) Physiological basis for high $\mathrm{CO}_{2}$ tolerance in marine ectothermic animals: preadaptation through lifestyle and ontogeny? Biogeosciences 6:2313-2331. doi: 10.5194/bg-6-23132009

Miller WA, Reynolds AC, Sobrino C, Riedel GF (2009) Shellfish face uncertain future in high $\mathrm{CO}_{2}$ world: influence of acidification on oyster larvae calcification and growth in estuaries. PloS One 4:e5661. doi: 10.1371/journal.pone.0005661

Miramand P, Bustamante P, Bentley D, Koueta N (2006) Variation of heavy metal concentrations ( $\mathrm{Ag}, \mathrm{Cd}, \mathrm{Co}, \mathrm{Cu}, \mathrm{Fe}, \mathrm{Pb}, \mathrm{V}, \mathrm{Zn}$ ) during the life cycle of the common cuttlefish Sepia officinalis. Sci Total Environ 361:132-143. doi: 10.1016/j.scitotenv.2005.10.018

Munday PL, Hernaman V, Dixson DL, Thorrold SR (2011) Effect of ocean acidification on otolith development in larvae of a tropical marine fish. Biogeosciences 8:1631-1641. doi: 10.5194/bg-81631-2011

Orr J, Fabry VJ, Aumont O, Bopp L, Doney SC, Feely RA et al. (2005) Anthropogenic ocean acidification over the twenty-first century and its impact on calcifying organisms. Nature 437:6816. 10.1038/nature04095

Palmer AR (1992) Calcification in marine molluscs: how costly is it? P Natl Acad Sci USA 89:1379-1382. doi: 10.1073/pnas.89.4.1379

Parker LM, Ross PM, O’Connor WA, Borysko L, Raftos DA, Pörtner, H-O (2012) Adult exposure influences offspring response to ocean acidification in oysters. Glob Change Biol 18:82-92. doi: $10.1111 / \mathrm{j} .1365-2486.2011 .02520 . \mathrm{x}$ 
Pechenik JA (2006) Larval experience and latent effects: metamorphosis is not a new beginning. Integr Comp Biol 46:323-333. doi: 10.1093/icb/icj028

Pierce GJ, Allcock L, Bruno I et al. (2010) Cephalopod biology and fisheries in Europe. ICES Cooperative Research Report, 303. ICES, Copenhagen, Denmark. ISBN 978-87-7482-078-9. http://oceanrep.geomar.de/10074/Politi Y, Arad T, Klein E, Weiner S, Addadi L (2004) Sea urchin spine calcite forms via a transient amorphous calcium carbonate phase. Science 306:1161-4. doi: 10.1126/science.1102289

Pörtner H-O, Farrell AP (2004) Physiology and Climate Change. Science 322:690-692. doi: 10.1126/science. 1163156

Pörtner H-O (2008) Ecosystem effects of ocean acidification in times of ocean warming: a physiologist's view. Mar Ecol Prog Ser 373:203-217. doi: 10.3354/meps07768

R Development Core Team (2008) R: A language and environment for statistical computing R Foundation for Statistical Computing, Vienna, Austria ISBN 3-900051-07-0, URL http://wwwRprojectorg

Riebesell U, Zondervan I, Rost B, Tortell PD, Zeebe RE, Morel FMM (2000) Reduced calcification of marine plankton in response to increased atmospheric $\mathrm{CO}_{2}$. Nature 407:364-367

Ries JB, Cohen AL, McCorkle DC (2009) Marine calcifiers exhibit mixed responses to $\mathrm{CO}_{2^{-}}$ induced ocean acidification. Geology 37:1131-1134. doi: 10.1130/G30210A.1

Rodhouse PG (1998) Physiological progenesis in cephalopod molluscs. Biol Bull 195:17-20

Rodolfo-Metalpa R, Lombardi C, Cocito S, Hall-Spencer JM, Gambi MC (2010) Effects of ocean acidification and high temperatures on the bryozoan Myriapora truncata at natural $\mathrm{CO}_{2}$ vents. Marine Ecol 31(3):447-456. doi: 10.1111/j.1439-0485.2009.00354.x

Rodolfo-Metalpa R, Houlbrèque F, Tambutté É. Et al. (2011) Coral and mollusc resistance to ocean acidification adversely affected by warming. Nature Clim Change 1:308-312

Rodriguez y Baena A, Metian M, Teyssié JL, Debroyer C, Warnau M (2006) Experimental evidence for ${ }^{234} \mathrm{Th}$ bioaccumulation in three Antarctic crustaceans: Potential implications for particle flux studies. Marine Chem 100:354-365. doi: 10.1016/j.marchem.2005.10.022

Rosa R, Seibel BA (2008) Synergistic effects of climate-related variables suggest future physiological impairment in a top oceanic predator. P Natl Acad Sci USA 105:20776-80. doi: 10.1073/pnas.0806886105

Seibel BA, Walsh PJ (2001) Potential impacts of $\mathrm{CO}_{2}$ injection on deep-sea biota. Science 294:319-320

Seibel BA, Fabry VJ (2003) Marine biotic response to elevated carbon dioxide. Adv Appl Biodivers Sci 4:59-67

Seibel BA, Walsh PJ (2003) Biological impacts of deep-sea carbon dioxide injection inferred from indices of physiological performance. J Exp Biol 206:641-650. doi: 10.1242/jeb.00141

Sherrard K (2000) Cuttlebone morphology limits habitat depth in eleven species of Sepia (Cephalopoda: Sepiidae). Biol Bull 198:404-414

Shiao J-C, Lin L-Y, Horng J-L, Hwang P-P, Kaneko T (2005) How can teleostean inner ear hair cells maintain the proper association with the accreting otolith? J Comp Neurol 488:331-341

Spero HJ, Bijma J, Lea DW, Bemis BE (1997) Effect of seawater carbonate concentration on foraminiferal carbon and oxygen isotopes. Nature 390:497-500. doi:10.1038/37333

Stumpp M, Wren J, Melzner F, Thorndyke MC, Dupont S (2011) $\mathrm{CO}_{2}$ induced seawater acidification impacts sea urchin larval development I: Elevated metabolic rates decrease scope for growth and induce developmental delay. Comp Biochem Phys A 160 (3):331-340. doi: 10.1016/j.cbpa.2011.06.022

Stumpp M, Trübenbach K, Brennecke D, Hu MY, Melzner F (2012) Resource allocation and extracellular acid-base status in the sea urchin Strongylocentrotus droebachiensis in response to $\mathrm{CO}_{2}$ induced seawater acidification. Aquat Toxicol 110-111:194-207. doi:10.1016/j.aquatox.2011.12.020 
Thomsen J, Melzner F (2010) Moderate seawater acidification does not elicit long-term metabolic depression in the blue mussel Mytilus edulis. Mar Biol 157:2667-76. doi: 10.1007/s00227-0101527-0

Thomsen J, Gutowska MA, Saphörster J, Heinemann A, Trübenbach K, Fietzke J, Hiebenthal C, Eisenhauer A, Körtzinger A, Wahl M, Melzner F (2010) Calcifying invertebrates succeed in a naturally $\mathrm{CO}_{2}$-rich coastal habitat but are threatened by high levels of future acidification. Biogeosciences 7:3879-3891

Touratier F, Goyet C (2011) Impact of the Eastern Mediterranean Transient on the distribution of anthropogenic $\mathrm{CO}_{2}$ and first estimate of acidification for the Mediterranean Sea. Deep-Sea Res PT I 58:1-15

Tunnicliffe V, Davies KTA, Butterfield DA, Embley RW, Rose JM, Chadwick Jr WW (2009) Survival of mussels in extremely acidic waters on a submarine volcano. Nature Geosci 2:344-8. doi: 10.1038/ngeo500

Venn A, Tambutté É, Holcomb M, Allemand D, Tambutté S (2011) Live Tissue Imaging Shows Reef Corals Elevate pH under Their Calcifying Tissue Relative to Seawater. PloS one, 6(5):e20013. doi:10.1371/journal.pone.0020013

Villanueva R, Bustamante P (2006) Composition in essential and non-essential elements of early stages of cephalopods and dietary effects on the elemental profiles of Octopus vulgaris paralarvae. Aquaculture 261:225-240. doi: 10.1016/j.aquaculture.2006.07.006

Waldbusser GG, Bergschneider H, Green MA (2010) Size-dependent pH effect on calcification in post-larval hard clam Mercenaria spp.. Mar Ecol Prog Ser 417:171-182

Weiss IM, Tuross N, Addadi L, Weiner S (2002) Mollusc larval shell formation: amorphous calcium carbonate is a precursor phase for aragonite. $J$ Exp Zool 293:478-91. doi: $10.1002 /$ jez.90004

Wood HL, Spicer JI, Widdicombe S (2008) Ocean acidification may increase calcification rates, but at a cost. Proc Roy Soc B 275:1767-73. doi: 10.1098/rspb.2008.0343

Zondervan I, Zeebe RE, Rost B, Riebesell U (2001) Decreasing marine biogenic calcification: A negative feedback on rising atmospheric $p \mathrm{CO}_{2}$. Global Biogeochem Cy 15:507-516 


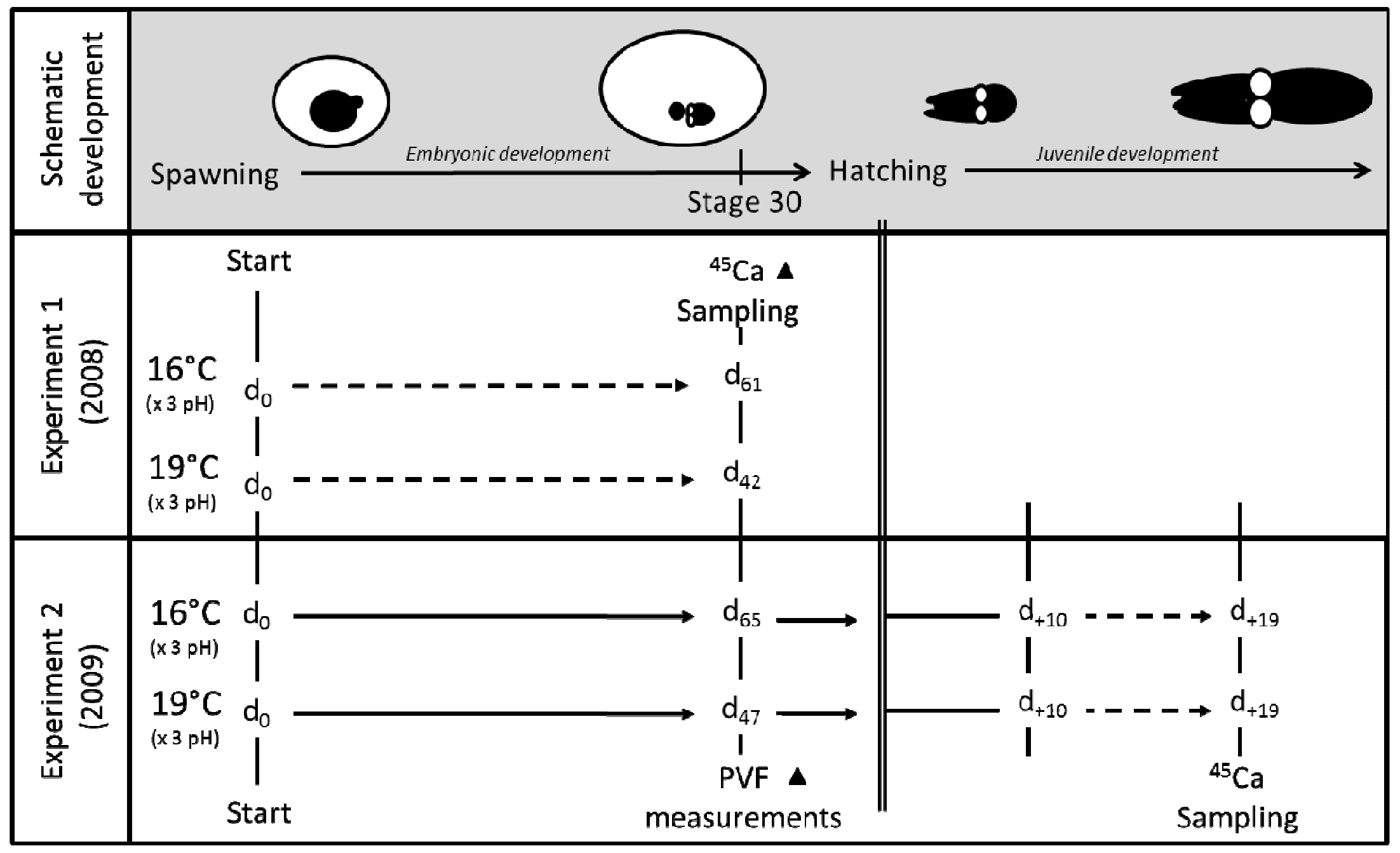

Fig. 1 Experimental design scheme (Experiments 1 and 2) set up to study the impact of temperature and pH along the embryonic and juvenile development of the cuttlefish (Sepia offcinalis). Dotted lines represent the exposure of animals to dissolved ${ }^{45} \mathrm{Ca}$ in seawater. For each ${ }^{445} \mathrm{Ca}$ sampling", measurements of the cuttlebone dry weight, body dry weight, ${ }^{45} \mathrm{Ca}$ content in the cuttlebone $\left(\mathrm{Q}_{\mathrm{ca}}\right)$ have been carried out. Fresh eggs were weighted at the end of the embryonic development ( $\boldsymbol{\Delta}$; stage 30$)$. 
Table 1 Carbonate system parameters during the experimental set-up in both 2008 (Experiment 1) and 2009 (Experiment 2). Results are expressed as mean $\pm \mathrm{SD}$. The partial pressure of $\mathrm{CO}_{2}\left(p \mathrm{CO}_{2}\right)$ and aragonite saturation state $\left(\Omega_{\mathrm{ar}}\right)$ were calculated for a seawater salinity of 38 , using the measured parameters in bold.

\begin{tabular}{|c|c|c|c|c|c|}
\hline Experiment & $\begin{array}{c}\mathrm{A}_{\mathrm{T}} \\
(\mu \mathrm{mol} \mathrm{kg})\end{array}$ & $\begin{array}{c}\text { Temperature } \\
\left({ }^{\circ} \mathrm{C}\right)\end{array}$ & $\mathrm{pH}_{\mathrm{T}}$ & $\begin{array}{l}p \mathrm{CO}_{2} \\
(\mu \mathrm{atm})\end{array}$ & $\Omega_{\mathrm{ar}}$ \\
\hline \multirow{6}{*}{ Experiment 1} & \multirow{6}{*}{$2597 \pm 12$} & \multirow{3}{*}{$16.0 \pm 0.1$} & $7.60 \pm 0.08$ & $1433 \pm 208$ & $1.21 \pm 0.31$ \\
\hline & & & $7.84 \pm 0.05$ & $775 \pm 83$ & $1.97 \pm 0.20$ \\
\hline & & & $8.11 \pm 0.09$ & $378 \pm 65$ & $3.35 \pm 0.63$ \\
\hline & & \multirow{3}{*}{$18.9 \pm 0.3$} & $7.58 \pm 0.08$ & $1517 \pm 273$ & $1.30 \pm 0.26$ \\
\hline & & & $7.86 \pm 0.12$ & $766 \pm 181$ & $2.32 \pm 0.73$ \\
\hline & & & $8.14 \pm 0.09$ & $393 \pm 83$ & $3.56 \pm 0.67$ \\
\hline \multirow{6}{*}{ Experiment 2} & \multirow{6}{*}{$2549 \pm 65$} & \multirow{3}{*}{$16.0 \pm 0.4$} & $7.60 \pm 0.09$ & $1381 \pm 30$ & $1.16 \pm 0.03$ \\
\hline & & & $7.81 \pm 0.04$ & $739 \pm 15$ & $1.97 \pm 0.04$ \\
\hline & & & $8.06 \pm 0.08$ & $376 \pm 11$ & $3.17 \pm 0.09$ \\
\hline & & \multirow{3}{*}{$19.1 \pm 0.5$} & $7.60 \pm 0.03$ & $1395 \pm 38$ & $1.30 \pm 0.04$ \\
\hline & & & $7.83 \pm 0.02$ & $741 \pm 22$ & $2.19 \pm 0.06$ \\
\hline & & & $8.03 \pm 0.06$ & $370 \pm 7$ & $3.46 \pm 0.06$ \\
\hline
\end{tabular}



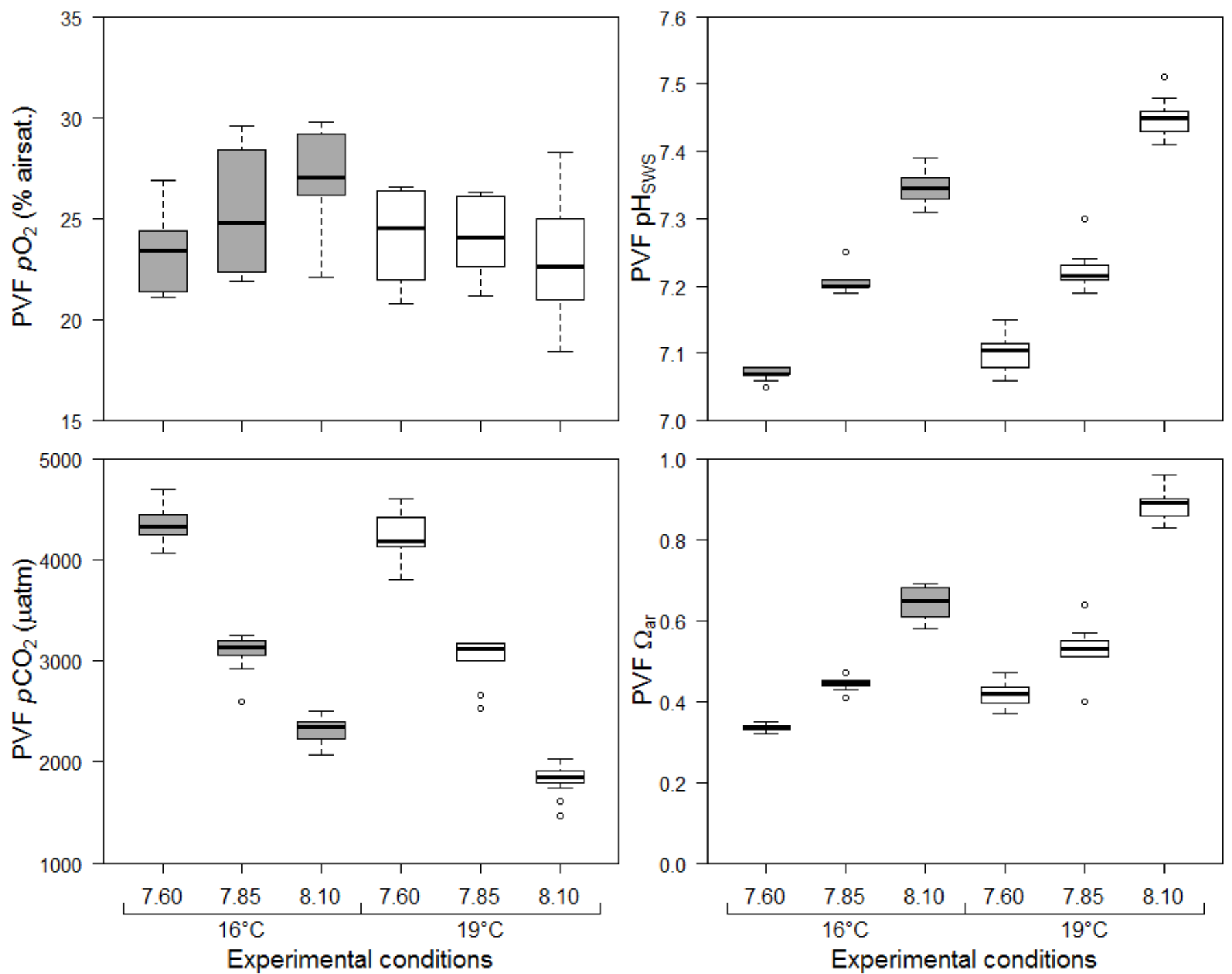

Fig. 2 Abiotic conditions in the perivitelline fluid (PVF) of $S$. officinalis eggs during Experiment 2 (stage $30 ; \mathrm{n}=8$ to 12 ) including $p \mathrm{O}_{2}(\%$ air saturation), $\mathrm{pH}$ (SWS scale), $p \mathrm{CO}_{2}(\mu \mathrm{atm})$ and $\Omega_{\mathrm{ar}}$ in the different experimental conditions $\left(\mathrm{pH}=7.60,7.85\right.$ and 8.10 ; temperature $=16^{\circ} \mathrm{C}$ and $19^{\circ} \mathrm{C}$ ). Results of the statistical analyses are reported in Table 2. 

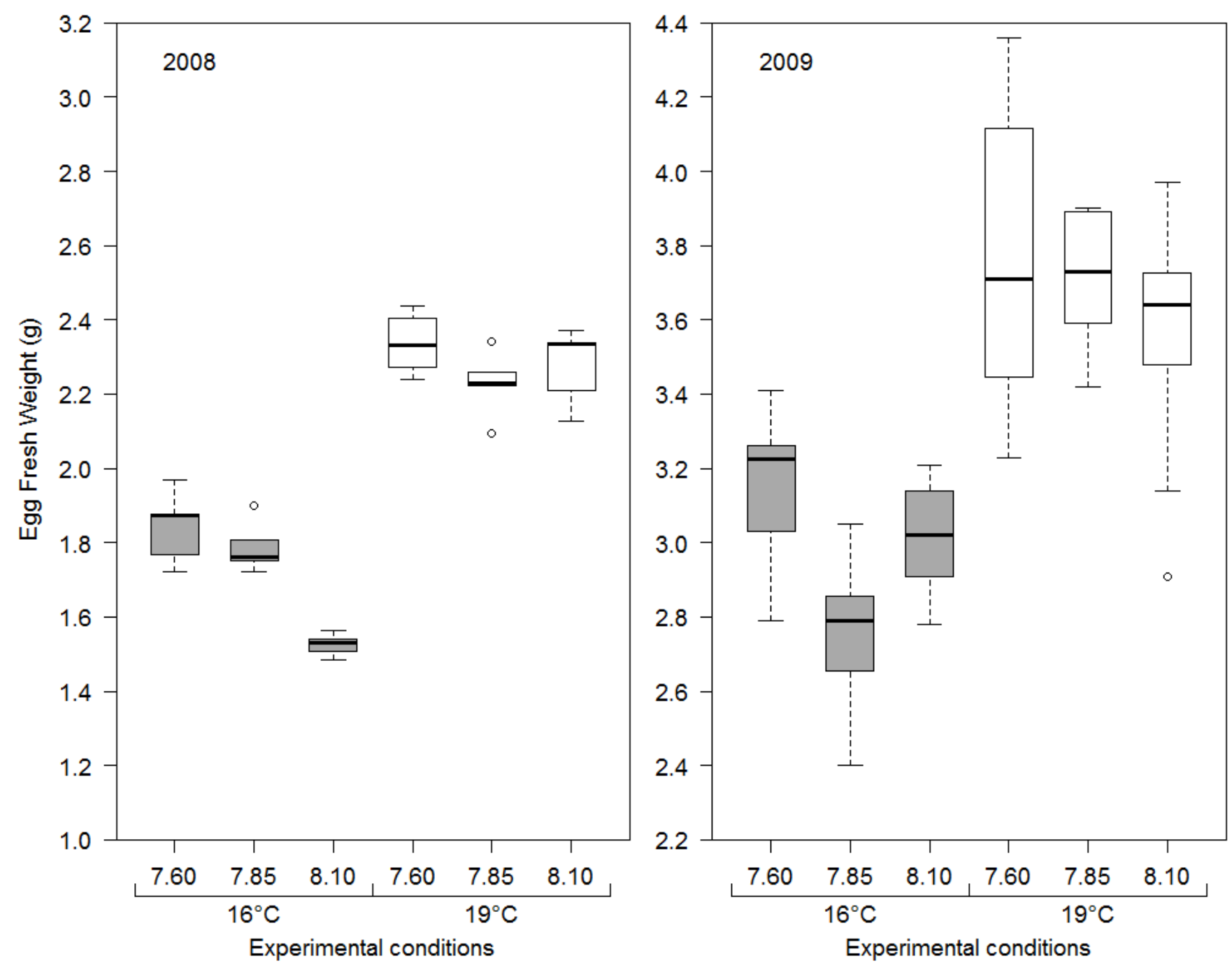

Fig. 3 Weights of S. officinalis nearly hatched eggs $(\mathrm{g}$; stage $30 ; \mathrm{n}=10)$ in the different experimental conditions $(\mathrm{pH}=7.60,7.85$ and 8.10 ; temperature $=16^{\circ} \mathrm{C}$ and $19^{\circ} \mathrm{C}$ ). Data are issued from two experiments carried out in 2008 (Experiment 1; left) and 2009 (Experiment 2; right; note the different scales). Results of the statistical analyses are reported in Table 2. 
Table 2 Two-way ANOVA analyses testing the influence of temperature (T; 16 vs. $\left.19^{\circ} \mathrm{C}\right), \mathrm{pH}(\mathrm{pH} ; 7.60,7.85$ and 8.10$)$ and their interactions ( $\mathrm{T} \times \mathrm{pH})$ on nearly hatched eggs (stage 30) regarding: $i$. the perivitelline-fluid ( $\mathrm{PVF}$ ) abiotic conditions $\left(p \mathrm{O}_{2}, \mathrm{pH} p \mathrm{CO}_{2}\right.$, and $\left.\Omega_{\mathrm{ar}}\right)$ and the $p \mathrm{CO}{ }_{2}$ gradient $\left(\Delta p \mathrm{CO}_{2}=\mathrm{PVF} p \mathrm{CO}_{2}\right.$ - seawater $p \mathrm{CO}_{2}$ ) during Experiment 2 ( $\mathrm{n}=8$ to 12 ) and ii. eggs fresh weight (Eggs $\mathrm{FW}$ ) both during Experiments 1 (2008) and 2 (2009) (n=10). Results in bold are significant.

\begin{tabular}{|c|c|c|c|c|c|c|c|c|c|c|c|c|}
\hline & & & $\mathrm{T}$ & & & & $\mathrm{pH}$ & & & & $\mathrm{T} \times \mathrm{pH}$ & \\
\hline & $\mathrm{df}$ & MS & $\mathrm{F}$ & $P$ & $\mathrm{df}$ & MS & $\mathrm{F}$ & $P$ & $\mathrm{df}$ & MS & $\mathrm{F}$ & $P$ \\
\hline $\mathrm{PVF}_{p} \mathrm{O}_{2}$ & 1 & 35.88 & $5.57 *$ & 0.02 & 2 & 8.27 & $1.28^{\mathrm{ns}}$ & 0.29 & 2 & 31.01 & $4.81 *$ & 0.01 \\
\hline PVF pH & 1 & 0.067 & $112.70 * * *$ & $1.10^{-14}$ & 2 & 0.48 & $816.45^{* * * *}$ & $<2.10^{-16}$ & 2 & 0.010 & $16.81 * * *$ & $2.10^{-6}$ \\
\hline $\mathrm{PVF} p \mathrm{CO}_{2}$ & 1 & 1747381 & $46.69 * * *$ & $8.10^{-9}$ & 2 & 23995501 & $641.18 * * *$ & $<2.10^{-16}$ & 2 & 281779 & $7.53 * *$ & 0.001 \\
\hline $\operatorname{PVF} \Omega_{\mathrm{ar}}$ & 1 & 0.38 & $283.46 * * *$ & $<2.10^{-16}$ & 2 & 0.80 & $596.65 * * *$ & $<2.10^{-16}$ & 2 & 0.042 & $31.34 * * *$ & $1.10^{-9}$ \\
\hline$\Delta p \mathrm{CO}_{2}$ & 1 & 1162398 & $31.06 * * *$ & $9.10^{-7}$ & 2 & 6558119 & $175.26 * * *$ & $<2.10^{-16}$ & 2 & 153672 & 4.11* & 0.02 \\
\hline Eggs $\mathrm{FW}_{2008}$ & 1 & 2.37 & $346.51 * * *$ & $9.10^{-16}$ & 2 & 0.09 & $13.02 * * *$ & $1.10^{-4}$ & 2 & 0.069 & $10.06 * * *$ & $6.10^{-4}$ \\
\hline Eggs $\mathrm{FW}_{2009}$ & 1 & 8.49 & $125.31 * * *$ & $7.10^{-16}$ & 2 & 0.37 & $5.43 * *$ & 0.007 & 2 & 0.26 & $3.80 *$ & 0.028 \\
\hline
\end{tabular}

$\mathrm{df}=$ degree of freedom; MS= mean squares; F=F-value. $P<0.001(* * *), P<0.01(* *), P<0.05(*), P<0.1(\dagger)$, ns= non-significant. 

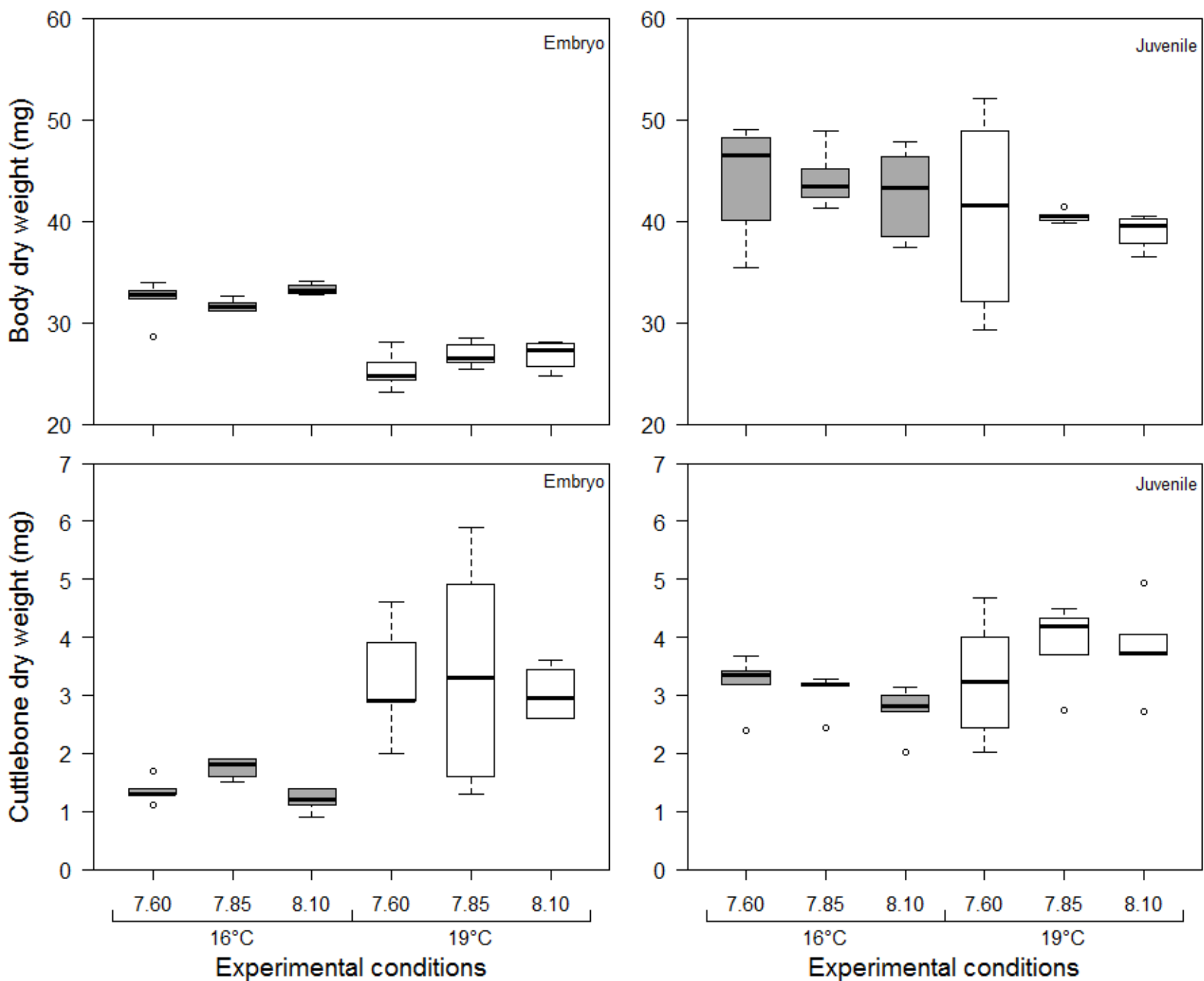

Fig. 4 Body (g; upper figures) and cuttlebone (mg; bottom figures) dry weight of $S$. officinalis embryos (left figures; stage 30; $\mathrm{n}=5)$ and juveniles (right figures; 19-days; $\mathrm{n}=5$ ) in the different experimental conditions $\left(\mathrm{pH}=7.60,7.85\right.$ and 8.10 ; temperature $=16^{\circ} \mathrm{C}$ and $19^{\circ} \mathrm{C}$ ). Results of the statistical analysis are reported in Table 3. 

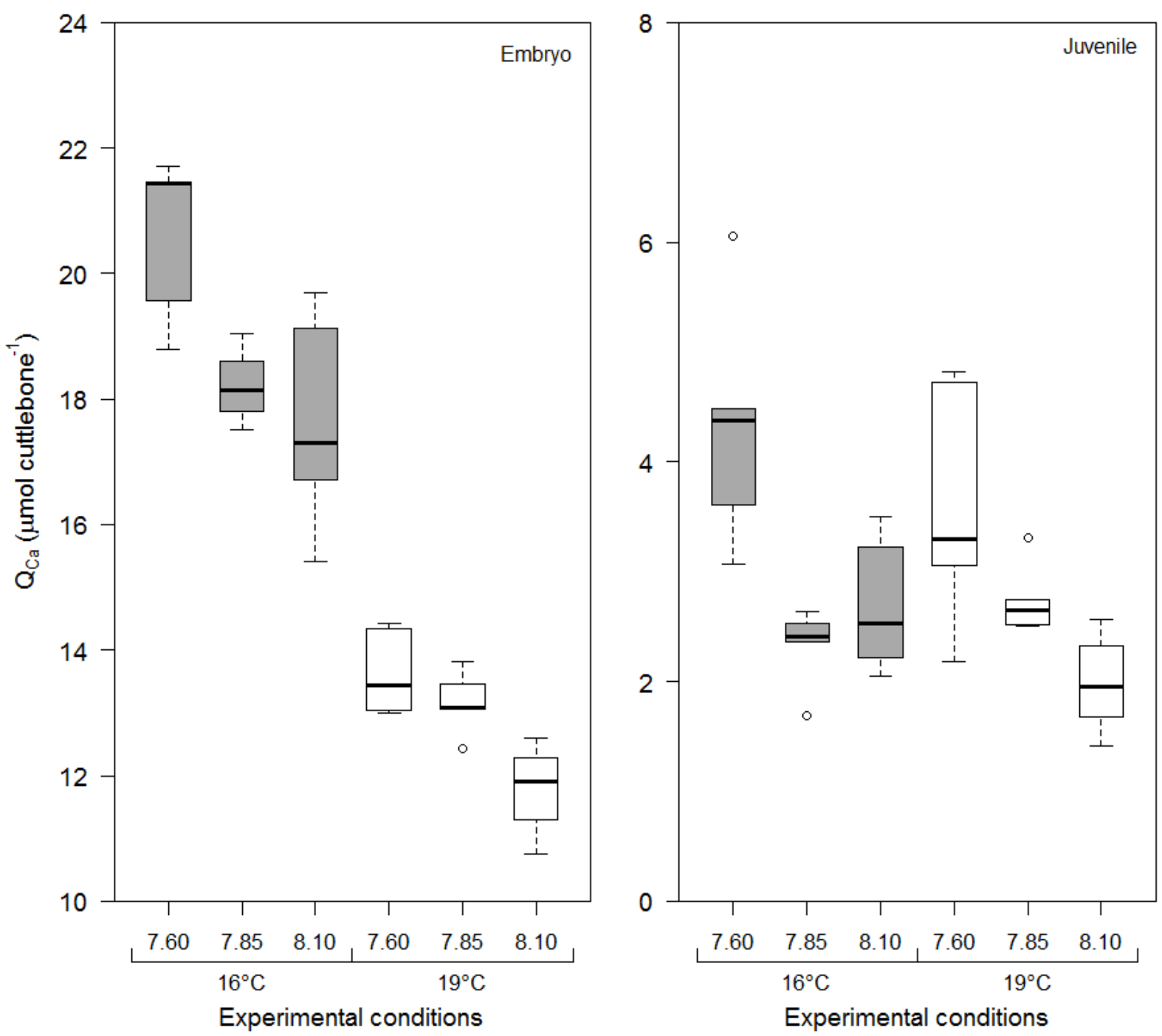

Fig. 5. Calcium-45 content ( $\mathrm{Q}_{\mathrm{Ca}}$ : $\mu$ mol cuttlebone ${ }^{-1} ; \mathrm{n}=5$ to 12 ) in cuttlebones of $S$. officinalis embryos (left; stage 30) and juveniles (right; 19days old) following incubation to ${ }^{45} \mathrm{Ca}$ in the different experimental con $\left(\mathrm{pH}=7.60,7.85\right.$ and 8.10; temperature $=16^{\circ} \mathrm{C}$ and $\left.19^{\circ} \mathrm{C}\right)$. Note the different scales for embryos and juveniles. Results of the statistical analysis are reported in Table 3. 
Table 3 Two-way ANOVA analyses testing the influence of Temperature $(\mathrm{T}), \mathrm{pH}(\mathrm{pH})$ conditions and their interactions $(\mathrm{T} \times \mathrm{pH})$ on body and cuttlebone dry weight and cuttlebone ${ }^{45} \mathrm{Ca}$ content $\left(\mathrm{Q}_{\mathrm{Ca}}, \mu\right.$ mol cuttlebone $\left.{ }^{-1}\right)$ at both the end of egg development $\left(\right.$ Embryo, $61 \mathrm{~d}$ at $16^{\circ} \mathrm{C}$ and $42 \mathrm{~d}$ at $19^{\circ} \mathrm{C}$ ) and after 19 days of juvenile life (Juvenile). Results in bold are significant.

\begin{tabular}{|c|c|c|c|c|c|c|c|c|c|c|c|c|c|}
\hline & & \multicolumn{4}{|c|}{$\mathrm{T}$} & \multicolumn{4}{|c|}{$\mathrm{pH}$} & \multicolumn{4}{|c|}{$\mathrm{T} \times \mathrm{pH}$} \\
\hline & & df & MS & $\mathrm{F}$ & $P$ & df & MS & $\mathrm{F}$ & $P$ & $\mathrm{df}$ & MS & $\mathrm{F}$ & $P$ \\
\hline \multirow{2}{*}{$\begin{array}{l}\text { Body Dry } \\
\text { Weight }\end{array}$} & Embryo & 1 & 269.22 & $131.37 * * *$ & $5.10^{-11}$ & 2 & 4.58 & $2.24^{\mathrm{ns}}$ & 0.13 & 2 & 2.92 & $1.43^{\mathrm{ns}}$ & 0.26 \\
\hline & Juvenile & 1 & 93.92 & $3.34 \dagger$ & 0.08 & 2 & 8.06 & $0.29^{\mathrm{ns}}$ & 0.75 & 2 & 0.38 & $0.013^{\mathrm{ns}}$ & 0.99 \\
\hline \multirow{2}{*}{$\begin{array}{l}\text { Cuttlebone } \\
\text { Dry Weight }\end{array}$} & Embryo & 1 & 23.71 & $25.38 * * *$ & $4.10^{-5}$ & 2 & 0.50 & $0.54^{\mathrm{ns}}$ & 0.59 & 2 & 0.038 & $0.040^{\mathrm{ns}}$ & 0.96 \\
\hline & Juvenile & 1 & 3.29 & $6.88 *$ & 0.015 & 2 & 0.16 & $0.32^{\mathrm{ns}}$ & 0.73 & 2 & 0.71 & $1.48^{\mathrm{ns}}$ & 0.25 \\
\hline \multirow{2}{*}{$\begin{array}{c}\text { Cuttlebone } \\
\qquad \mathrm{Q}_{\mathrm{Ca}}\end{array}$} & Embryo & 1 & 249.76 & $224.66^{* * * *}$ & $2.10^{-13}$ & 2 & 13.93 & $12.53 * * *$ & $2.10^{-4}$ & 2 & 2.29 & $2.06^{\mathrm{ns}}$ & 0.15 \\
\hline & Juvenile & 1 & 0.83 & $1.45^{\mathrm{ns}}$ & 0.24 & 2 & 7.85 & $13.71 * * *$ & $1.10^{-4}$ & 2 & 1.06 & $1.85^{\mathrm{ns}}$ & 0.18 \\
\hline
\end{tabular}

$\mathrm{df}=$ degree of freedom; MS= mean squares; F=F-value. $P<0.001(* * *), P<0.01(* *), P<0.05(*), P<0.1(\dagger)$, ns= non-significant. 